\title{
A Comparative Study on Energy Use and Cost Analysis of Rice Varieties Under Traditional and Semi-Mechanized Farming Systems in North of Iran
}

\author{
Ebrahim Azarpour and Maral Moraditochaee \\ Additional information is available at the end of the chapter
}

http://dx.doi.org/10.5772/51165

\section{Introduction}

Rice is an important food crop for a large proportion of the world's population. It is staple food in the diet of the population of Asia, Latin America, and Africa. Rice provides 35-60\% of the dietary calories consumed by more than 3 billion people [12]. Globally, it is also the second most cultivated cereal after wheat. Unlike wheat, $95 \%$ of the world's rice is grown in less developed nations, primarily in Asia, Africa, and Latin America. China and India are the largest rice producing and consuming countries in the world. By the year 2025, it is estimated that it will be necessary to produce about $60 \%$ more rice than what is currently produced to meet the food needs of a growing world population. In addition, the land available for crop production is decreasing steadily due to urban growth and land degradation. Hence, increases in rice production will have to come from the same or an even less amount of land. This means appropriate rice production practices should be adopted to improve rice yield per unit area [13]. Guilan province has allocated more 35 and 42 percent of paddy production and cultivation land area cultivation area of Iran, respectively. In this province more than 181 exploiters on productive and talented areas with more than 230000 hectares, are busy rice farming [26]. Indeed, rice cultivation is considered the most important agricultural activity in this province and the economy of the province is also based on agriculture, with rice cultivation in top. Most of the under cultivation area of local varieties in Guilan are including Hashemi and Alikazemi. Most of the under cultivation area of breed varieties in Guilan are including Khazar, Hybrid and Gohar.

The system of agricultural productions in the world has been deeply changed because of using mechanization, chemical fertilizers and poisons and reformed seeds and as a result 
considerable changes in the direction of consumed energy in agricultural section have been created and caused higher relationship to the energy of fossil fuel. This change in the pattern of energy consumption has created problems include warming environment results from green house gases and water and soil pollutions and etc. Nowadays, agricultural sector for providing more food needed the population increase like other sectors has depended to energy sources like electricity and fossil fuels [14]. Energy has been a key input of agriculture since the age of subsistence agriculture. It is an established fact worldwide that agricultural production is positively correlated with energy input [28]. Agriculture is both a producer and consumer of energy. It uses large quantities of locally available noncommercial energy, such as seed, manure and animate energy, as well as commercial energies, directly and indirectly, in the form of diesel, electricity, fertilizer, plant protection, chemical, irrigation water, machinery etc. Efficient use of these energies helps to achieve increased production and productivity and contributes to the profitability and competitiveness of agriculture sustainability in rural living [28]. Energy use in agriculture has been increasing in response to increasing population, limited supply of arable land and a desire for higher standards of living [18]. However, more intensive energy use has brought some important human health and environment problems so efficient use of inputs has become important in terms of sustainable agricultural production [31]. Recently, environmental problems resulting from energy production, conversion and utilization increased public awareness in all sectors of the public, industry and government in both developed and developing countries It is predicted that fossil fuels will be the primary source of energy for the next several decades [8, 9]. The level of fossil fuel dependence differs significantly between developed and developing countries. Although total primary fossil energy input into farm production is comparable between developed countries and developing countries, as illustrated in "Figure 1", developed countries use more than four times the energy per capita (8.0 gigajoules/capita/year) than developing countries (1.7 GJ/capita/year). Moreover, Figure 5 further reveals very different distribution of energy use across agricultural inputs. For developing countries, nitrogen fertilizer accounts for more than half the energy inputs, with fuel and irrigation forming the next largest inputs. By contrast, in developed countries, fuel and machinery account for more than half the inputs, with nitrogen accounting for about one quarter. Efficient use of resources is one of the major assets of eco-efficient and sustainable production, in agriculture [10]. Energy use is one of the key indicators for developing more sustainable agricultural practices [29] and efficient use of energy is one of the principal requirements of sustainable agriculture [18]. It is important, therefore, to analyses cropping systems in energy terms and to evaluate alternative solutions, especially for arable crops, which account for more than half of the primary sector energy consumption [27].

Agricultural systems are complex, and understanding this complexity requires systematic research, but resources for agricultural research are limited. The field experiments investigate a number of variables under a few site-specific conditions. Crop simulation models consider the complex interactions of weather, soil properties, and management factors, which influence crop performance. Mechanistic models are very helpful in deciding 
the best management options for optimizing crop growth and the yield. In the middle of 1990s, Rice Research Institute of Iran (IRRI), Wageningen University, and the Research Centre developed the ORYZA model series to simulate the growth and development of tropical lowland rice. In 2001, a new version of the ORYZA model was released that improved and incorporated all previous versions into one model called ORYZA2000 [7]. The model ORYZA2000, simulates the growth and development of rice under conditions of potential production, water and nitrogen limitations.

The aims of the study were to survey input energy in local and breed varieties rice production under two farming systems condition (traditional and semi-mechanized), to investigate the energy consumption and to make an economic analysis of rice in Guilan province of Iran.
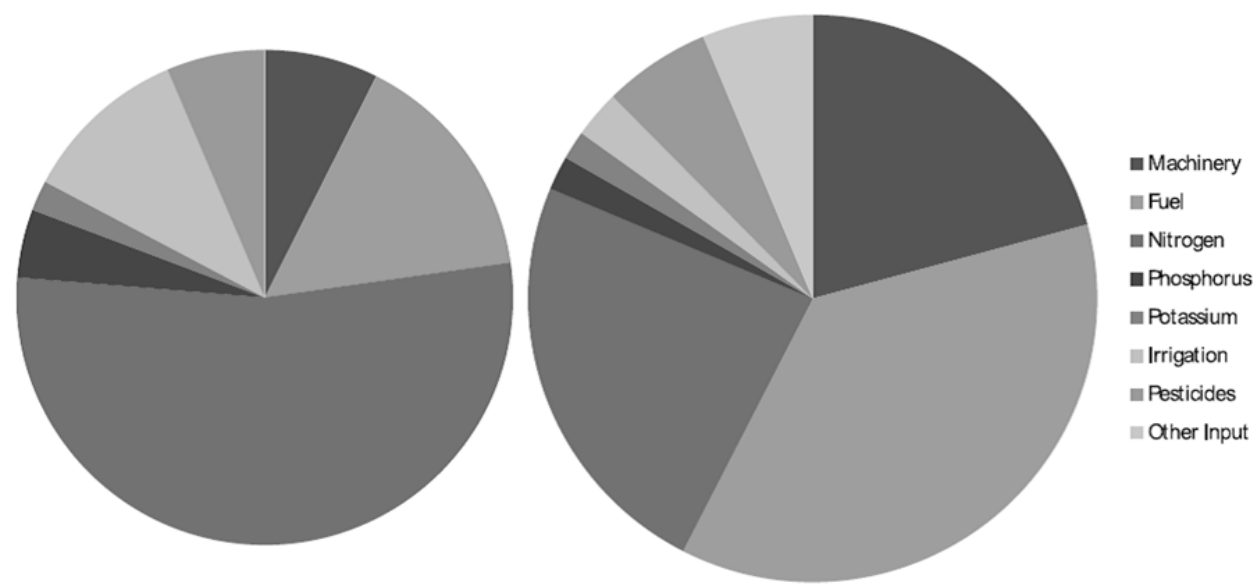

Figure 1. Distribution of farm energy inputs in developing countries (left) and in developed countries (right)

\section{Materials and methods}

In order to gather the required data in this study, information related to 72 farms in Guilan province during the agricultural year 2010 was studied. The Location of studied region in north of Iran was presented in "Figure 2". The random sampling of production agro ecosystems was done within whole population and the size of each sample was determined by using bottom equation [18].

$$
n=\frac{N \times s^{2} \times t^{2}}{(N-1) d^{2}+s^{2}+t^{2}}
$$

In the formula, $\mathrm{n}$ is the required sample size, $\mathrm{s}$ is the standard deviation, $\mathrm{t}$ is the $\mathrm{t}$ value at $95 \%$ confidence limit (1.96), $\mathrm{N}$ is the number of holding in target population and $\mathrm{d}$ is the acceptable error. 


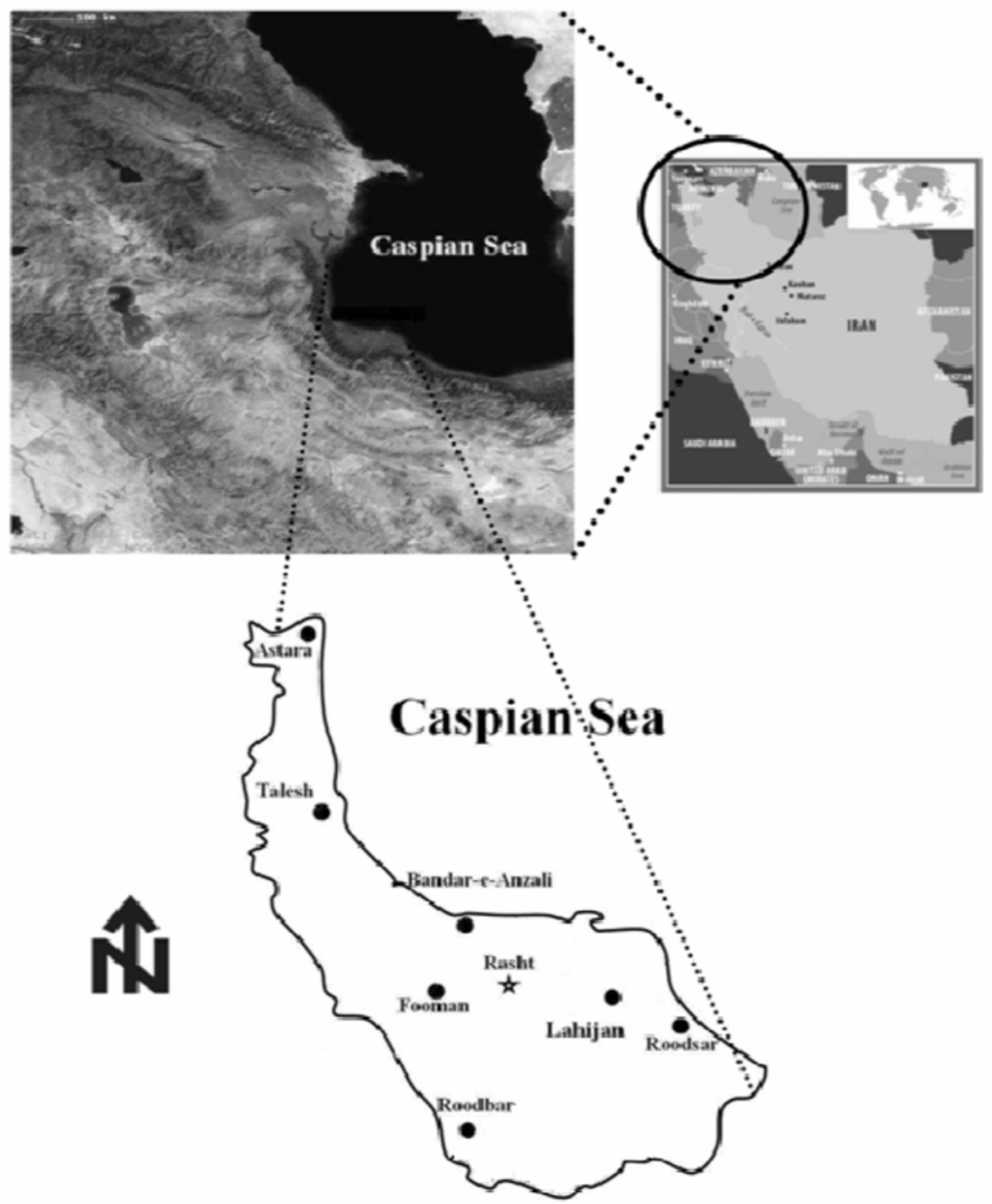

Figure 2. Location of the study area

Cultivated varieties in these farms include local varieties (Hashemi and Alikazemi) and breed varieties (Khazar, Hybrid (GRH1) and Gohar (SA13)). Farming methods in these farms include traditional system and semi-mechanized system. In semi-mechanized system in addition to tiller and thrasher, transforming machine and reaping machine are used for plant out and reaping respectively. 
Efficient use of the energy resources is vital in terms of increasing production, productivity, competitiveness of agriculture as well as sustainability of rural living. Energy auditing is one of the most common approaches to examining energy efficiency and environmental impact of the production system. It enables researchers to calculate output-input ratio, relevant indicators, and energy use patterns in an agricultural activity. Moreover, the energy audit provides sufficient data to establish functional forms to investigate the relationship between energy inputs and outputs. The amount of inputs used in agricultural production practices (human labor, machinery, diesel fuel, chemical fertilizers, poison fertilizers, water and seeds) were calculated per hectare and then, these data were converted to forms of energy to evaluate the output-input analysis. In order to calculate output and input energy, these input data and amount of output yield were multiplied with the coefficient of energy equivalent. Energy equivalents of inputs and output were converted into energy on area unit. The previous researches "Table 1 " were used to determine the energy equivalents' coefficients [15, 19, 20, 21, 22, 23, 24, 25, 30, 31]. Firstly, the amounts of inputs used in the production of rice were specified in order to calculate the energy equivalences in the study. Energy input include human labor, machinery, diesel fuel, chemical fertilizer, chemical poison, water and seed amounts and output yield include paddy of rice.

In this research, energy indices (energy use efficiency, energy ratio, energy productivity, energy intensity, net energy gain and water and energy productivity) based on the energy equivalents of the inputs and output "Table 2" were calculated according to bottom equations $[15,19,20,21,22,23,24,25,30,31]$.

$$
\begin{gathered}
\text { Energy use efficiency }=\frac{\text { Output energy }(\mathrm{Mj} / \mathrm{ha})}{\text { Input energy }(\mathrm{Mj} / \mathrm{ha})} \\
\text { Energy production }=\frac{\text { Grain yield }(\mathrm{Kg} / \mathrm{ha})}{\text { Input energy }(\mathrm{Mj} / \mathrm{ha})} \\
\text { Energy specific }=\frac{\text { Input energy }(\mathrm{Mj} / \mathrm{ha})}{\text { Grain yield }(\mathrm{Kg} / \mathrm{ha})}
\end{gathered}
$$

Water and energy productivity $=\frac{\text { Yield output }(\mathrm{Kg} / \mathrm{ha})}{\text { Water applied }(\mathrm{M} 3 / \mathrm{ha}) \times \text { Input energy }(\mathrm{Mj} / \mathrm{ha})}$

Net energy gain = Output energy $(\mathrm{Mj} / \mathrm{ha})-$ Input energy $(\mathrm{Mj} / \mathrm{ha})$

The input energy is also classified into direct and indirect and renewable and nonrenewable forms energy equivalents for different inputs and outputs in agricultural production. Indirect energy consists of seeds, chemical fertilizer, chemical poison, and machinery energy while direct energy covered human labor, water and diesel fuel used in the rice production. Non-renewable energy includes diesel fuel, chemical fertilizer, chemical poison and machinery and renewable energy consists of human labor, water and seed $[2,4$, $5,6]$. 


\begin{tabular}{|c|c|c|c|c|c|c|}
\hline Parameter & Hashemi & Alikazemi & Khazar & Hybrid & Gohar & $\begin{array}{c}\text { Energy } \\
\text { equivalent }\end{array}$ \\
\hline \multicolumn{7}{|c|}{ Traditional system } \\
\hline \multicolumn{7}{|c|}{ Input } \\
\hline Human labor (h/ha) & 94.3 & 94.3 & 94.3 & 94.3 & 94.3 & 1.96 \\
\hline Machinery (h/ha) & 37.2 & 37.2 & 37.2 & 37.2 & 37.2 & 62.7 \\
\hline Diesel fuel (1/ha) & 127.2 & 127.2 & 127.2 & 127.2 & 127.2 & 56.31 \\
\hline Nitrogen (kg/ha) & 125 & 125 & 180 & 230 & 230 & 69.5 \\
\hline Phosphorus(kg/ha) & 60 & 60 & 80 & 100 & 100 & 12.44 \\
\hline Potassium (kg/ha) & 110 & 110 & 150 & 200 & 200 & 11.15 \\
\hline Herbicide (l/ha) & 3 & 3 & 3 & 3 & 3 & 85 \\
\hline Fungicide (1/ha) & 2 & 2 & 2 & 2 & 2 & 160 \\
\hline Insecticide (1/ha) & 2 & 2 & 1 & 1 & 1 & 99 \\
\hline Water $\left(\mathrm{m}^{3} / \mathrm{ha}\right)$ & 10000 & 10000 & 10000 & 10000 & 10000 & 1.02 \\
\hline Seed (kg/ha) & 90 & 90 & 70 & 30 & 30 & 17 \\
\hline \multicolumn{7}{|c|}{ Output } \\
\hline Paddy (kg/ha) & 3520 & 4180 & 4840 & 6600 & 8360 & 14.7 \\
\hline Straw (kg/ha) & 4437 & 5706 & 6607 & 9010 & 11413 & 12.5 \\
\hline Husk (kg/ha) & 813 & 1045 & 1210 & 1650 & 2090 & 13.8 \\
\hline Biomass (kg/ha) & 8770 & 10931 & 12657 & 17260 & 21863 & 13.67 \\
\hline \multicolumn{7}{|c|}{ Semi-mechanized system } \\
\hline \multicolumn{7}{|c|}{ Input } \\
\hline Human labor (h/ha) & 73.7 & 73.7 & 73.7 & 73.7 & 73.7 & 1.96 \\
\hline Machinery (h/ha) & 47.3 & 47.3 & 47.3 & 47.3 & 47.3 & 62.7 \\
\hline Diesel fuel (l/ha) & 142.1 & 142.1 & 142.1 & 142.1 & 142.1 & 56.31 \\
\hline Nitrogen (kg/ha) & 125 & 125 & 180 & 230 & 230 & 69.5 \\
\hline Phosphorus(kg/ha) & 60 & 60 & 80 & 100 & 100 & 12.44 \\
\hline Potassium (kg/ha) & 110 & 110 & 150 & 200 & 200 & 11.15 \\
\hline Herbicide (l/ha) & 3 & 3 & 3 & 3 & 3 & 85 \\
\hline Fungicide (l/ha) & 2 & 2 & 2 & 2 & 2 & 160 \\
\hline Insecticide (l/ha) & 2 & 2 & 1 & 1 & 1 & 99 \\
\hline Water (m³/ha) & 10000 & 10000 & 10000 & 10000 & 10000 & 1.02 \\
\hline Seed (kg/ha) & 70 & 70 & 50 & 20 & 20 & 17 \\
\hline \multicolumn{7}{|c|}{ Output } \\
\hline Paddy (kg/ha) & 4000 & 4750 & 5500 & 7500 & 9500 & 14.7 \\
\hline Straw (kg/ha) & 5461 & 6485 & 7508 & 10239 & 12969 & 12.5 \\
\hline Husk (kg/ha) & 1000 & 1188 & 1375 & 1875 & 2375 & 13.8 \\
\hline Biomass (kg/ha) & 10461 & 12423 & 14383 & 19614 & 24844 & 13.67 \\
\hline
\end{tabular}

Table 1. Amounts of input-output used and energy equivalent in varieties rice production under traditional system and semi-mechanized system condition 


\begin{tabular}{|c|c|c|c|c|c|}
\hline Parameter & Hashemi & Alikazemi & Khazar & Hybrid & Gohar \\
\hline \multicolumn{6}{|c|}{ Traditional system } \\
\hline \multicolumn{6}{|c|}{ Input } \\
\hline Human labor (h/ha) & 184.83 & 184.83 & 184.83 & 184.83 & 184.83 \\
\hline Machinery (h/ha) & 2332.44 & 2332.44 & 2332.44 & 2332.44 & 2332.44 \\
\hline Diesel fuel (1/ha) & 7162.63 & 7162.63 & 7162.63 & 7162.63 & 7162.63 \\
\hline Nitrogen (kg/ha) & 8687.5 & 8687.5 & 12510 & 15985 & 15985 \\
\hline Phosphorus(kg/ha) & 746.4 & 746.4 & 995.2 & 1244 & 1244 \\
\hline Potassium (kg/ha) & 1226.5 & 1226.5 & 1672.5 & 2230 & 2230 \\
\hline Herbicide (l/ha) & 255 & 255 & 255 & 255 & 255 \\
\hline Fungicide (1/ha) & 320 & 320 & 320 & 320 & 320 \\
\hline Insecticide (1/ha) & 198 & 198 & 99 & 99 & 99 \\
\hline Water $\left(\mathrm{m}^{3} / \mathrm{ha}\right)$ & 10200 & 10200 & 10200 & 10200 & 10200 \\
\hline Seed (kg/ha) & 1530 & 1530 & 1190 & 510 & 510 \\
\hline \multicolumn{6}{|c|}{ Output } \\
\hline Paddy (kg/ha) & 51744 & 61446 & 71148 & 97020 & 122892 \\
\hline Straw (kg/ha) & 55463 & 71325 & 82588 & 112625 & 142663 \\
\hline Husk (kg/ha) & 11219 & 14421 & 16698 & 22770 & 28842 \\
\hline Biomass (kg/ha) & 119857 & 149390 & 172979 & 235887 & 298794 \\
\hline \multicolumn{6}{|c|}{ Semi-mechanized system } \\
\hline \multicolumn{6}{|c|}{ Input } \\
\hline Human labor (h/ha) & 144.45 & 144.45 & 144.45 & 144.45 & 144.45 \\
\hline Machinery (h/ha) & 2965.71 & 2965.71 & 2965.71 & 2965.71 & 2965.71 \\
\hline Diesel fuel (l/ha) & 8001.65 & 8001.65 & 8001.65 & 8001.65 & 8001.65 \\
\hline Nitrogen (kg/ha) & 8687.5 & 8687.5 & 12510 & 15985 & 15985 \\
\hline Phosphorus(kg/ha) & 746.4 & 746.4 & 995.2 & 1244 & 1244 \\
\hline Potassium (kg/ha) & 1226.5 & 1226.5 & 1672.5 & 2230 & 2230 \\
\hline Herbicide (l/ha) & 255 & 255 & 255 & 255 & 255 \\
\hline Fungicide (l/ha) & 320 & 320 & 320 & 320 & 320 \\
\hline Insecticide (1/ha) & 198 & 198 & 99 & 99 & 99 \\
\hline Water (m³/ha) & 10200 & 10200 & 10200 & 10200 & 10200 \\
\hline Seed (kg/ha) & 1190 & 1190 & 850 & 340 & 340 \\
\hline \multicolumn{6}{|c|}{ Output } \\
\hline Paddy (kg/ha) & 58800 & 69825 & 80850 & 110250 & 139650 \\
\hline Straw (kg/ha) & 68263 & 81063 & 93850 & 127988 & 162113 \\
\hline Husk (kg/ha) & 13800 & 16394 & 18975 & 25875 & 32775 \\
\hline Biomass (kg/ha) & 142967 & 169781 & 196568 & 268058 & 339535 \\
\hline
\end{tabular}

Table 2. Input-output energy for varieties rice under traditional system and semi-mechanized system condition 
In order to calculate energy balance indices, these input data and amount of output yield were multiplied with the coefficient of energy balance equivalent. Energy balance equivalents of inputs and output were converted into energy on area unit. The previous researches "Table 3 " were used to determine the energy balance equivalents' coefficients [2, $4,5,6]$ By using of consumed data as inputs and total production as output, and their concern equivalent energy, indicators of energy balance were calculated "Table 4".

\begin{tabular}{|c|c|c|c|c|c|c|}
\hline Parameter & Hashemi & Alikazemi & Khazar & Hybrid & Gohar & $\begin{array}{c}\text { Energy balance } \\
\text { equivalent }\end{array}$ \\
\hline \multicolumn{7}{|c|}{ Traditional system } \\
\hline \multicolumn{7}{|c|}{ Input } \\
\hline Human labor (h/ha) & 848.7 & 848.7 & 848.7 & 848.7 & 848.7 & 500 \\
\hline Machinery (h/ha) & 37.2 & 37.2 & 37.2 & 37.2 & 37.2 & 90000 \\
\hline Diesel fuel (1/ha) & 127.2 & 127.2 & 127.2 & 127.2 & 127.2 & 9237 \\
\hline Nitrogen (kg/ha) & 57.5 & 57.5 & 82.8 & 105.8 & 105.8 & 17600 \\
\hline Phosphorus(kg/ha) & 12.6 & 12.6 & 16.8 & 21 & 21 & 3190 \\
\hline Potassium (kg/ha) & 45.1 & 45.1 & 61.5 & 82 & 82 & 1600 \\
\hline $\begin{array}{l}\text { Chemical Poison } \\
\text { (l/ha) }\end{array}$ & 5 & 5 & 5 & 5 & 5 & 27170 \\
\hline Water (m³/ha) & 10000 & 10000 & 10000 & 10000 & 10000 & 272.2 \\
\hline Seed (kg/ha) & 90 & 90 & 70 & 30 & 30 & 6513 \\
\hline $\begin{array}{l}\text { Depreciation for per } \\
\text { diesel fuel (L) }\end{array}$ & 106.85 & 106.85 & 106.85 & 106.85 & 106.85 & 9583 \\
\hline \multicolumn{7}{|c|}{ Semi-mechanized system } \\
\hline \multicolumn{7}{|c|}{ Input } \\
\hline Human labor (h/ha) & 663.3 & 663.3 & 663.3 & 663.3 & 663.3 & 500 \\
\hline Machinery (h/ha) & 47.3 & 47.3 & 47.3 & 47.3 & 47.3 & 90000 \\
\hline Diesel fuel (l/ha) & 142.1 & 142.1 & 142.1 & 142.1 & 142.1 & 9237 \\
\hline Nitrogen (kg/ha) & 57.5 & 57.5 & 82.8 & 105.8 & 105.8 & 17600 \\
\hline Phosphorus(kg/ha) & 12.6 & 12.6 & 16.8 & 21 & 21 & 3190 \\
\hline Potassium (kg/ha) & 45.1 & 45.1 & 61.5 & 82 & 82 & 1600 \\
\hline $\begin{array}{l}\text { Chemical Poison } \\
(1 / \mathrm{ha})\end{array}$ & 5 & 5 & 5 & 5 & 5 & 27170 \\
\hline Water $\left(\mathrm{m}^{3} / \mathrm{ha}\right)$ & 10000 & 10000 & 10000 & 10000 & 10000 & 272.2 \\
\hline Seed (kg/ha) & 70 & 70 & 50 & 20 & 20 & 6513 \\
\hline $\begin{array}{l}\text { Depreciation for per } \\
\text { diesel fuel (L) }\end{array}$ & 119.36 & 119.36 & 119.36 & 119.36 & 119.36 & 9583 \\
\hline
\end{tabular}

Table 3. Amounts of input used and energy balance equivalent in varieties rice production under traditional system and semi-mechanized system condition 


\begin{tabular}{|c|c|c|c|c|c|}
\hline Parameter & Hashemi & Alikazemi & Khazar & Hybrid & Gohar \\
\hline \multicolumn{6}{|c|}{ Traditional system } \\
\hline \multicolumn{6}{|c|}{ Input } \\
\hline Parameter & Hashemi & Alikazemi & Khazar & Hybrid & Gohar \\
\hline Human labor (h/ha) & 424350 & 424350 & 424350 & 424350 & 424350 \\
\hline Machinery (h/ha) & 3348000 & 3348000 & 3348000 & 3348000 & 3348000 \\
\hline Diesel fuel (l/ha) & 1174946 & 1174946 & 1174946 & 1174946 & 1174946 \\
\hline Nitrogen $(\mathrm{kg} / \mathrm{ha})$ & 1012000 & 1012000 & 1457280 & 1862080 & 1862080 \\
\hline Phosphorus(kg/ha) & 40194 & 40194 & 53592 & 66990 & 66990 \\
\hline Potassium (kg/ha) & 72160 & 72160 & 98400 & 131200 & 131200 \\
\hline Chemical Poison (l/ha) & 135850 & 135850 & 135850 & 135850 & 135850 \\
\hline Water $\left(\mathrm{m}^{3} / \mathrm{ha}\right)$ & 2722000 & 2722000 & 2722000 & 2722000 & 2722000 \\
\hline Seed $(\mathrm{kg} / \mathrm{ha})$ & 586170 & 586170 & 455910 & 195390 & 195390 \\
\hline $\begin{array}{l}\text { Depreciation for per } \\
\text { diesel fuel (L) }\end{array}$ & 1023924 & 1023924 & 1023924 & 1023924 & 1023924 \\
\hline \multicolumn{6}{|c|}{ Semi-mechanized system } \\
\hline \multicolumn{6}{|c|}{ Input } \\
\hline Human labor (h/ha) & 331650 & 331650 & 331650 & 331650 & 331650 \\
\hline Machinery (h/ha) & 4257000 & 4257000 & 4257000 & 4257000 & 4257000 \\
\hline Diesel fuel (1/ha) & 1312578 & 1312578 & 1312578 & 1312578 & 1312578 \\
\hline Nitrogen (kg/ha) & 1012000 & 1012000 & 1457280 & 1862080 & 1862080 \\
\hline Phosphorus(kg/ha) & 40194 & 40194 & 53592 & 66990 & 66990 \\
\hline Potassium (kg/ha) & 72160 & 72160 & 98400 & 131200 & 131200 \\
\hline Chemical Poison $(1 /$ ha $)$ & 135850 & 135850 & 135850 & 135850 & 135850 \\
\hline Water $\left(\mathrm{m}^{3} / \mathrm{ha}\right)$ & 2722000 & 2722000 & 2722000 & 2722000 & 2722000 \\
\hline Seed (kg/ha) & 455910 & 455910 & 325650 & 130260 & 130260 \\
\hline $\begin{array}{c}\text { Depreciation for per } \\
\text { diesel fuel (L) }\end{array}$ & 1143865 & 1143865 & 1143865 & 1143865 & 1143865 \\
\hline
\end{tabular}

Table 4. Input energy in varieties rice production under traditional and semi-mechanized system condition from calculated indicators of energy balance energy

Cluster analysis and correlation analysis of energy indices and balance energy indices for rice production were obtained by SPSS software. Yield function of paddy yield, straw yield, husk yield and biomass yield for rice production was obtained by STATISCA software. Simulation growth indices of rice cultivars were obtained by model ORYZA2000 "Figure 3" [7].

In the last part of the study, the economic analysis of varieties rice production under traditional and semi-mechanized system condition was investigated. Net profit, gross profit and benefit to cost ratio was calculated. The gross value of production, net return and benefit to cost ratio were calculated using the following equations (Mohammadi et al., 2008): 


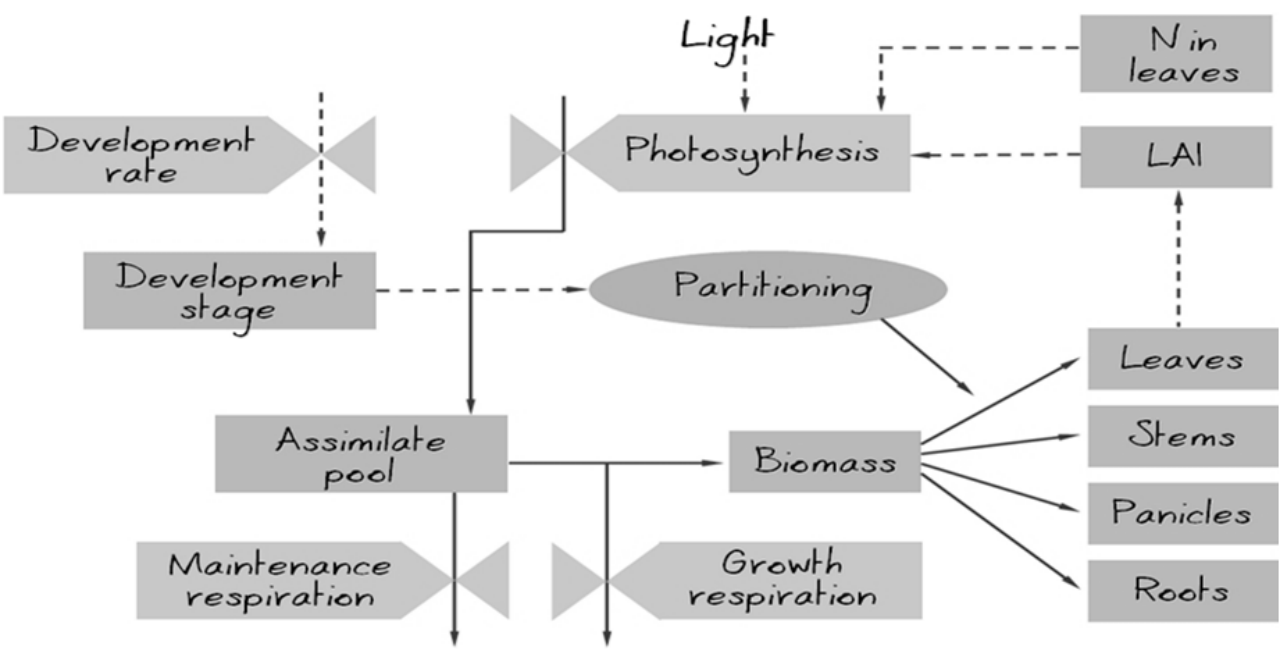

Figure 3. The model ORYZA2000 structure

Gross value of production $(\$ / \mathrm{ha})=$ Yield $(\mathrm{kg} / \mathrm{ha}) \times$ Sale price $(\$ / \mathrm{kg})$

Net return $(\$ / \mathrm{ha})=$ Gross value of production $(\$ /$ ha $)$ - Total cost of production $(\$ / \mathrm{ha})$

$$
\begin{gathered}
\text { Productivity }(\mathrm{kg} / \$)=\frac{\text { Yield }(\mathrm{kg} / \mathrm{ha})}{\text { Total cost of production }(\$ / \mathrm{ha})} \\
\text { Benefit to cost ratio }=\frac{\text { Gross value of production }(\$ / \mathrm{ha})}{\text { Total cost of production }(\$ / \mathrm{ha})}
\end{gathered}
$$

\section{Results and discussions}

\subsection{Analysis of energy indices in varieties rice production under traditional and semi-mechanized system condition}

In "Figure 4" (traditional system) and "Figure 5" (semi-mechanized system), seven groups of reserves of production of studied figures according to percentage of total energy of reserve is observed. Results showed that highest energy consumption in all varieties was related to chemical fertilizer. The amount of further use of fertilizer and also raising of equivalent amounts of energy in this reserve showed this subject. The energy of water reserve, fuel, poison, machines, seed and human labor are in next grades.

Rice plants require fertilizer during vegetative stage to promote growth and tillering, which in turn, determines potential number of panicles. Fertilizer contributes to spikelet production during early panicle formation stage, and contributes to sink size during the late panicle formation stage. Fertilizer also plays a role in grain filling, improving the photosynthetic capacity, and promoting carbohydrate accumulation in culms and leaf sheaths [1]. 
Results of "Tables 5 and 6" showed that breed varieties (Khazar, Hybrid and Gohar) because of suitable genetic specifications have higher operation in compared with local varieties (Hashemi and Alikazemi), highest paddy yield (9500 kg/ha), straw yield (12969 kg/ha), husk yield $(2375 \mathrm{~kg} / \mathrm{ha})$ and biomass yield $(24844 \mathrm{~kg} / \mathrm{ha})$ of semi-mechanized system and paddy yield (8360 Kg/ha), straw yield (11413 kg/ha), husk yield (2090 kg/ha) and biomass yield $(21863 \mathrm{~kg} / \mathrm{ha})$ of traditional system observed in Gohar rice.

Breed varieties because of accepting higher fertilizer have further input energy than local varieties under two farming systems condition "Tables 5 and 6". Traditional system because of consumption higher fertilizer and seed has further input energy than semi-mechanized system "Tables 3 and 4".

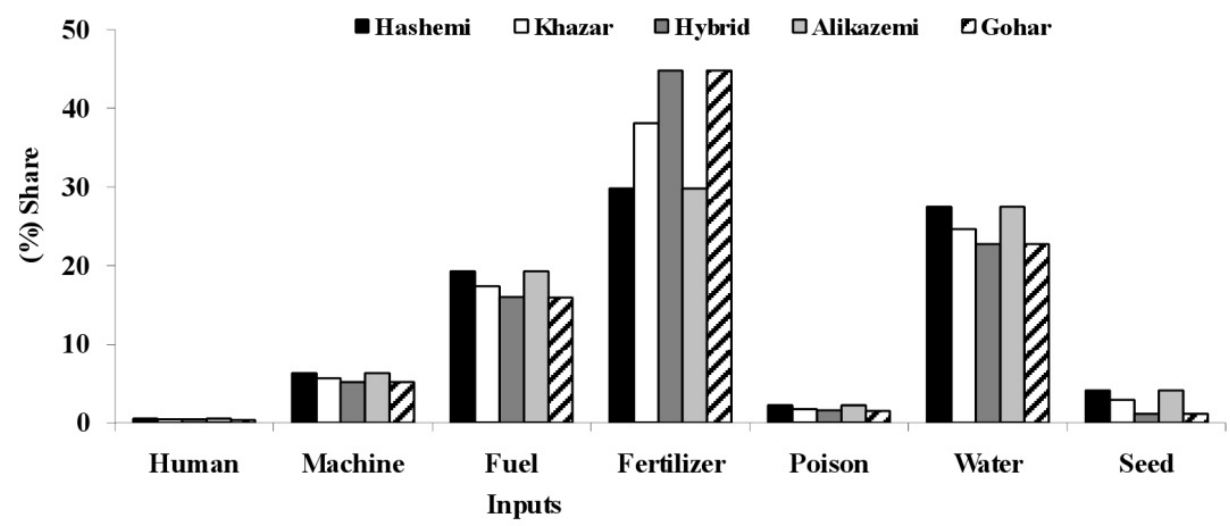

Figure 4. The share (\%) production inputs for varieties rice under traditional system condition

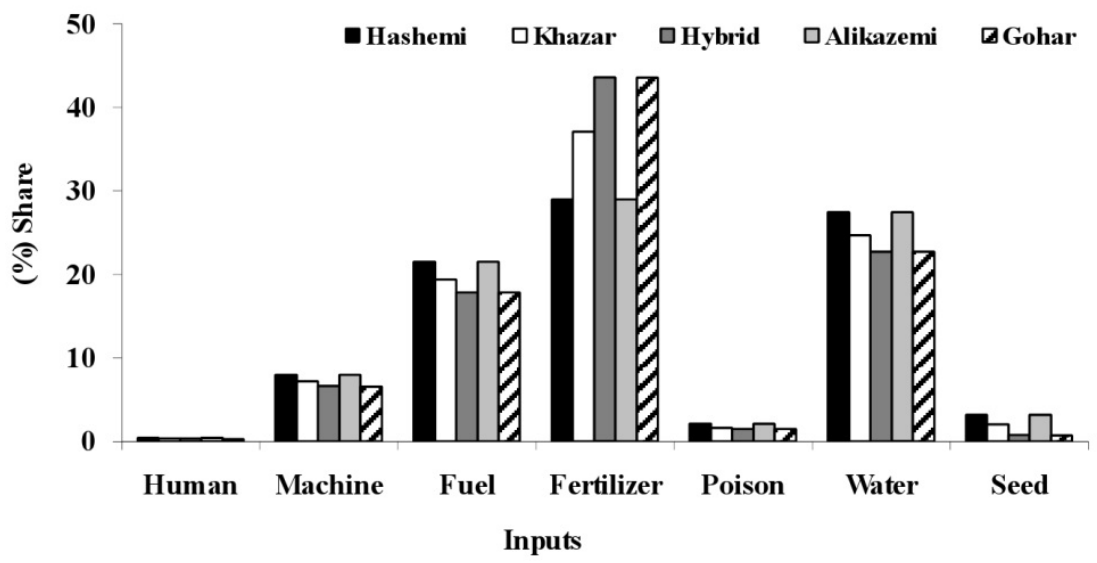

Figure 5. The share $(\%)$ production inputs for varieties rice under semi-mechanized system condition

Semi-mechanized system because of producing higher paddy yield, straw yield, husk yield and biomass yield than traditional system of has higher output energy "Tables 5 and 6". Breed varieties (Khazar, Hybrid and Gohar) because of suitable genetic specifications have 


\begin{tabular}{|c|c|c|c|c|c|c|}
\hline Item & Unit & Hashemi & Alikazemi & Khazar & Hybrid & Gohar \\
\hline \multicolumn{7}{|c|}{ Paddy } \\
\hline Yield & $\mathrm{kg} / \mathrm{ha}$ & 3520 & 4180 & 4840 & 6600 & 8360 \\
\hline Input energy & $\mathrm{MJ} / \mathrm{ha}$ & 32843 & 32843 & 36922 & 40523 & 40523 \\
\hline Output energy & $\mathrm{MJ} / \mathrm{ha}$ & 51744 & 61446 & 71148 & 97020 & 122892 \\
\hline Energy ratio & - & 1.58 & 1.87 & 1.93 & 2.39 & 3.03 \\
\hline Energy intensity & $\mathrm{MJ} / \mathrm{kg}$ & 9.33 & 7.86 & 7.63 & 6.14 & 4.85 \\
\hline Energy productivity & $\mathrm{kg} / \mathrm{MJ}$ & 0.11 & 0.13 & 0.13 & 0.16 & 0.21 \\
\hline Net energy gain & $\mathrm{MJ} / \mathrm{ha}$ & 18901 & 28603 & 34226 & 56497 & 82369 \\
\hline $\begin{array}{l}\text { Water and energy } \\
\text { productivity }\end{array}$ & $\mathrm{g} / \mathrm{m}^{3} . \mathrm{MJ}$ & 0.011 & 0.012 & 0.013 & 0.016 & 0.020 \\
\hline \multicolumn{7}{|c|}{ Straw } \\
\hline Yield & $\mathrm{kg} / \mathrm{ha}$ & 4437 & 5706 & 6607 & 9010 & 11413 \\
\hline Input energy & $\mathrm{MJ} / \mathrm{ha}$ & 32843 & 32843 & 36922 & 40523 & 40523 \\
\hline Output energy & $\mathrm{MJ} / \mathrm{ha}$ & 55463 & 71325 & 82588 & 112625 & 142663 \\
\hline Energy ratio & - & 1.69 & 2.17 & 2.24 & 2.78 & 3.52 \\
\hline Energy intensity & $\mathrm{MJ} / \mathrm{kg}$ & 7.40 & 5.76 & 5.59 & 4.50 & 3.55 \\
\hline Energy productivity & $\mathrm{kg} / \mathrm{MJ}$ & 0.14 & 0.17 & 0.18 & 0.22 & 0.28 \\
\hline Net energy gain & $\mathrm{MJ} / \mathrm{ha}$ & 22620 & 38482 & 45666 & 72102 & 102140 \\
\hline $\begin{array}{l}\text { Water and energy } \\
\text { productivity }\end{array}$ & $\mathrm{g} / \mathrm{m}^{3} . \mathrm{MJ}$ & 0.013 & 0.017 & 0.018 & 0.022 & 0.028 \\
\hline \multicolumn{7}{|c|}{ Husk } \\
\hline Yield & $\mathrm{kg} / \mathrm{ha}$ & 813 & 1045 & 1210 & 1650 & 2090 \\
\hline Input energy & $\mathrm{MJ} / \mathrm{ha}$ & 32843 & 32843 & 36922 & 40523 & 40523 \\
\hline Output energy & $\mathrm{MJ} / \mathrm{ha}$ & 11219 & 14421 & 16698 & 22770 & 28842 \\
\hline Energy ratio & - & 0.34 & 0.44 & 0.45 & 0.56 & 0.71 \\
\hline Energy intensity & $\mathrm{MJ} / \mathrm{kg}$ & 40.40 & 31.43 & 30.51 & 24.56 & 19.39 \\
\hline Energy productivity & $\mathrm{kg} / \mathrm{MJ}$ & 0.02 & 0.03 & 0.03 & 0.04 & 0.05 \\
\hline Net energy gain & MJ/ha & -21624 & -18422 & -20224 & -17753 & -11681 \\
\hline $\begin{array}{l}\text { Water and energy } \\
\text { productivity }\end{array}$ & $\mathrm{g} / \mathrm{m}^{3} . \mathrm{MJ}$ & 0.002 & 0.003 & 0.003 & 0.004 & 0.005 \\
\hline \multicolumn{7}{|c|}{ Biomass } \\
\hline Yield & $\mathrm{kg} / \mathrm{ha}$ & 8770 & 10931 & 12657 & 17260 & 21863 \\
\hline Input energy & $\mathrm{MJ} / \mathrm{ha}$ & 32843 & 32843 & 36922 & 40523 & 40523 \\
\hline Output energy & $\mathrm{MJ} / \mathrm{ha}$ & 119857 & 149390 & 172979 & 235887 & 298794 \\
\hline Energy ratio & - & 3.65 & 4.55 & 4.69 & 5.82 & 7.37 \\
\hline Energy intensity & $\mathrm{MJ} / \mathrm{kg}$ & 3.74 & 3.00 & 2.92 & 2.35 & 1.85 \\
\hline Energy productivity & $\mathrm{kg} / \mathrm{MJ}$ & 0.27 & 0.33 & 0.34 & 0.43 & 0.54 \\
\hline Net energy gain & $\mathrm{MJ} / \mathrm{ha}$ & 87013 & 116547 & 136057 & 195364 & 258271 \\
\hline $\begin{array}{l}\text { Water and energy } \\
\text { productivity }\end{array}$ & $\mathrm{g} / \mathrm{m}^{3} . \mathrm{MJ}$ & 0.027 & 0.033 & 0.034 & 0.043 & 0.054 \\
\hline
\end{tabular}

Table 5. Energy indices for varieties rice under traditional system condition 
higher output energy in compared with local varieties (Hashemi and Alikazemi). Highest output energy with averages 139650, 162113, 32775 and $339535 \mathrm{MJ} / \mathrm{ha}$ of semi-mechanized system and with averages 122892, 142663, 28842 and $298794 \mathrm{MJ} / \mathrm{ha}$ of traditional system observed in Gohar rice "Tables 5 and 6".

Energy ratio in two farming systems and five varieties showed that positive output of energy production and being further of energy output of semi-mechanized system than traditional system and breed varieties than local varieties (tables 5 and 6).

Results of energy intensity under two farming systems condition "Tables 5 and 6" showed that local varieties require of further input from production of paddy yield, straw yield, husk yield and biomass yield than breed varieties.

Results of energy productivity under two farming systems condition "Tables 5 and 6" were showed that in breed varieties lieu of imported energy consumption have higher energy productions than local varieties.

Net energy gain in two farming systems and five varieties showed that highest net energy gain of semi-mechanized system than traditional system and breed varieties than local varieties. Highest net energy gain with averages 97865, 120328, -9010 and $297750 \mathrm{MJ} / \mathrm{ha}$ of semi-mechanized system and with averages 82369, 102140, -11681 and $258271 \mathrm{MJ} / \mathrm{ha}$ of traditional system observed in Gohar rice "Tables 5 and 6"

Direct, indirect energy, renewable, non-renewable, \% direct, \% indirect energy, \% renewable and $\%$ non-renewable in two farming systems and five varieties were showed "Tables 7". In two farming systems and five varieties were showed that direct energy and \% direct energy as compared with indirect energy and \% indirect energy; renewable energy and \% renewable energy as compared with nonrenewable energy and \% nonrenewable energy have lower amount "Tables 7". The amount of higher consumption of machinery and diesel fuel in semi-mechanized system lead to increasing indirect energy in this system in compared with traditional system. The amount of higher consumption of chemical fertilizer in breed varieties lead to increasing indirect energy in these varieties in compared with local varieties. Results showed that, lower amount of consumption of seed and human labor in semi-mechanized system in compared with traditional system leads to being lower of renewable energy in semi-mechanized system than traditional system "Tables 7". Lower amount of consumption of seed in breed varieties in compared with local varieties leads to being lower of renewable energy in breed varieties than local varieties. The amount of higher consumption of chemical fertilizer in breed varieties in compared with local varieties leads to increasing nonrenewable energy in these breed varieties than local varieties. The share of direct and indirect energy from total reserve of energy and share of renewable and nonrenewable energies from total reserve of energy "Tables 7" in studied farming systems and varieties were that the percentage of direct energy is lowest than percentage of indirect energy and percentage of renewable energy in producing rice is lowest than nonrenewable energies that this required to consider saving in energy consumption. 


\begin{tabular}{|c|c|c|c|c|c|c|}
\hline Item & Unit & Hashemi & Alikazemi & Khazar & Hybrid & Gohar \\
\hline \multicolumn{7}{|c|}{ Paddy } \\
\hline Yield & $\mathrm{kg} / \mathrm{ha}$ & 4000 & 4750 & 5500 & 7500 & 9500 \\
\hline Input energy & $\mathrm{MJ} / \mathrm{ha}$ & 33935 & 33935 & 38014 & 41785 & 41785 \\
\hline Output energy & $\mathrm{MJ} / \mathrm{ha}$ & 58800 & 69825 & 80850 & 110250 & 139650 \\
\hline Energy ratio & - & 1.73 & 2.06 & 2.13 & 2.64 & 3.34 \\
\hline Energy intensity & $\mathrm{MJ} / \mathrm{kg}$ & 8.48 & 7.14 & 6.91 & 5.57 & 4.40 \\
\hline Energy productivity & $\mathrm{kg} / \mathrm{MJ}$ & 0.12 & 0.14 & 0.14 & 0.18 & 0.23 \\
\hline Net energy gain & $\mathrm{MJ} / \mathrm{ha}$ & 24865 & 35890 & 42836 & 68465 & 97865 \\
\hline $\begin{array}{l}\text { Water and energy } \\
\text { productivity }\end{array}$ & $\mathrm{g} / \mathrm{m}^{3} \cdot \mathrm{MJ}$ & 0.012 & 0.014 & 0.014 & 0.018 & 0.022 \\
\hline \multicolumn{7}{|c|}{ Straw } \\
\hline Yield & $\mathrm{kg} / \mathrm{ha}$ & 5461 & 6485 & 7508 & 10239 & 12969 \\
\hline Input energy & $\mathrm{MJ} / \mathrm{ha}$ & 33935 & 33935 & 38014 & 41785 & 41785 \\
\hline Output energy & $\mathrm{MJ} / \mathrm{ha}$ & 68263 & 81063 & 93850 & 127988 & 162113 \\
\hline Energy ratio & - & 2.01 & 2.39 & 2.47 & 3.06 & 3.88 \\
\hline Energy intensity & $\mathrm{MJ} / \mathrm{kg}$ & 6.21 & 5.23 & 5.06 & 4.08 & 3.22 \\
\hline Energy productivity & $\mathrm{kg} / \mathrm{MJ}$ & 0.16 & 0.19 & 0.20 & 0.25 & 0.31 \\
\hline Net energy gain & $\mathrm{MJ} / \mathrm{ha}$ & 34327 & 47127 & 55836 & 86203 & 120328 \\
\hline $\begin{array}{l}\text { Water and energy } \\
\text { productivity }\end{array}$ & $\mathrm{g} / \mathrm{m}^{3} \cdot \mathrm{MJ}$ & 0.016 & 0.019 & 0.019 & 0.024 & 0.030 \\
\hline \multicolumn{7}{|c|}{ Husk } \\
\hline Yield & $\mathrm{kg} / \mathrm{ha}$ & 1000 & 1188 & 1375 & 1875 & 2375 \\
\hline Input energy & $\mathrm{MJ} / \mathrm{ha}$ & 33935 & 33935 & 38014 & 41785 & 41785 \\
\hline Output energy & $\mathrm{MJ} / \mathrm{ha}$ & 13800 & 16394 & 18975 & 25875 & 32775 \\
\hline Energy ratio & - & 0.41 & 0.48 & 0.50 & 0.62 & 0.78 \\
\hline Energy intensity & $\mathrm{MJ} / \mathrm{kg}$ & 33.94 & 28.56 & 27.65 & 22.29 & 17.59 \\
\hline Energy productivity & $\mathrm{kg} / \mathrm{MJ}$ & 0.03 & 0.04 & 0.04 & 0.04 & 0.06 \\
\hline Net energy gain & $\mathrm{MJ} / \mathrm{ha}$ & -20135 & -17541 & -19039 & -15910 & -9010 \\
\hline $\begin{array}{l}\text { Water and energy } \\
\text { productivity }\end{array}$ & $\mathrm{g} / \mathrm{m}^{3} . \mathrm{MJ}$ & 0.003 & 0.003 & 0.004 & 0.004 & 0.006 \\
\hline \multicolumn{7}{|c|}{ Biomass } \\
\hline Yield & $\mathrm{kg} / \mathrm{ha}$ & 10461 & 12423 & 14383 & 19614 & 24844 \\
\hline Input energy & $\mathrm{MJ} / \mathrm{ha}$ & 33935 & 33935 & 38014 & 41785 & 41785 \\
\hline Output energy & $\mathrm{MJ} / \mathrm{ha}$ & 142967 & 169781 & 196568 & 268058 & 339535 \\
\hline Energy ratio & - & 4.21 & 5.00 & 5.17 & 6.42 & 8.13 \\
\hline Energy intensity & $\mathrm{MJ} / \mathrm{kg}$ & 3.24 & 2.73 & 2.64 & 2.13 & 1.68 \\
\hline Energy productivity & $\mathrm{kg} / \mathrm{MJ}$ & 0.31 & 0.37 & 0.38 & 0.47 & 0.59 \\
\hline Net energy gain & MJ/ha & 109032 & 135846 & 158554 & 226273 & 297750 \\
\hline $\begin{array}{l}\text { Water and energy } \\
\text { productivity }\end{array}$ & $\mathrm{g} / \mathrm{m}^{3} . \mathrm{MJ}$ & 0.031 & 0.037 & 0.038 & 0.047 & 0.059 \\
\hline
\end{tabular}

Table 6. Energy indices for varieties rice under semi-mechanized system condition 


\begin{tabular}{lccccc}
\hline \multicolumn{1}{c}{ Item } & Hashemi & Alikazemi & Khazar & Hybrid & Gohar \\
\hline & \multicolumn{2}{c}{ Traditional system } & & & \\
Direct energy (MJ/ha) & 17547 & 17547 & 17547 & 17547 & 17547 \\
Direct energy (\%) & 53.43 & 53.43 & 47.53 & 43.30 & 43.30 \\
Indirect energy (MJ/ha) & 15296 & 15296 & 19375 & 22976 & 22976 \\
Indirect energy (\%) & 46.57 & 46.57 & 52.47 & 56.70 & 56.70 \\
Renewable energy (MJ/ha) & 11915 & 11915 & 11575 & 10895 & 10895 \\
Renewable energy (\%) & 36.28 & 36.28 & 31.35 & 26.89 & 26.89 \\
Nonrenewable energy & 20928 & 20928 & 25347 & 29628 & 29628 \\
(MJ/ha) & 63.72 & 63.72 & 68.65 & 73.11 & 73.11 \\
Nonrenewable energy (\%) & Semi-mechanized system & & & \\
& 18346 & 18346 & 18346 & 18346 & 18346 \\
Direct energy (MJ/ha) & 54.06 & 54.06 & 48.26 & 43.91 & 43.91 \\
Direct energy (\%) & 15589 & 15589 & 19667 & 23439 & 23439 \\
Indirect energy (MJ/ha) & 45.94 & 45.94 & 51.74 & 56.09 & 56.09 \\
Indirect energy (\%) & 11534 & 11534 & 11194 & 10684 & 10684 \\
Renewable energy (MJ/ha) & 33.99 & 33.99 & 29.45 & 25.57 & 25.57 \\
Renewable energy (\%) & 22401 & 22401 & 26819 & 31100 & 31100 \\
Nonrenewable energy & 66.01 & 66.01 & 70.55 & 74.43 & 74.43 \\
(MJ/ha) & & & & \\
Nonrenewable energy (\%) & & & & & \\
\hline
\end{tabular}

Table 7. Division of the energy for varieties rice under traditional and semi-mechanized system condition

Moradi and Azarpour [23] with study of energy indices for native and breed rice varieties production in Iran were recorded the highest grain yield, input energy, output energy, energy ratio, energy productivity and Net energy gain obtained from breed varieties as compared with local varieties. Eskandari Cherati et al. [11] with study energy survey of mechanized and traditional rice production system in Mazandaran province of Iran showed that the total energy used for semi-mechanized and traditional rice production system was 67217.95 and $67356.28 \mathrm{MJ} / \mathrm{ha}$, respectively. Based on the results, irrigation and fertilizer in both systems with 50232 and $7610.32 \mathrm{MJ} /$ ha was the most input energy. Total energy output of the traditional method was $127.5 \mathrm{GJ} / \mathrm{ha}$ and that of the semi-mechanized was 132.26 $\mathrm{GJ} / \mathrm{ha}$. Parallel to the mechanization level of operations that increased, consumption of fuel and machinery energy increased similarly, but the human labor and seed energy consumption dropped. The renewable energy in the traditional and semi-mechanized systems was 3168.3 (4.70\% total energy) and $2312.1 \mathrm{MJ} /$ ha $(3.44 \%)$, respectively. Energy ratio and energy productivity in traditional and semi-mechanized systems was 3 and 3.08, and 0.111 and $0.116 \mathrm{~kg} / \mathrm{MJ} 116.0$, respectively. Nonetheless, net energy gain and specific energy showed that energy efficiency of semi-mechanized systems was more than the traditional 
system. Khan et al. [16] with energy requirement and economic analysis of rice production in western part of Pakistan Energy requirement and economic analysis of rice production in western part of Pakistan revealed that energy consumption and rice yield were 5,756 kWh and 3.23 tons per hectare on Bullock Operated Farms (BOF) and 11,162 kWh and 4.12 tons per hectare on Tractor Operated Farms (TOF). Consumption of animate energy on BOF was more than TOF due to heavy use of animate energy in land preparation operation. Result also showed that energy efficiency i.e. output-input ratio on BOF (6.32) was higher than TOF (4.16). Cost of production remained lower on BOF than TOF, however, the yield and consequently crop values and net return were higher on TOF than BOF.

Khan et al. [17] with study energy requirements and economic analysis of wheat, rice and barley production in Australia revealed that chemical fertilizer consumed 47, 43 and $29 \%$ of the total energy inputs on wheat, rice and barley growing farms, respectively. Wheat consumed 3028, rice 6699 and barley consumed $2175 \mathrm{kWhha}^{-1}$. Similarly, wheat utilized 2852, rice 17754 and barley $856 \mathrm{~m}^{3} \mathrm{ha}^{-1}$. Average energy output of wheat was 27874, rice 44885 , and barley obtained $17865 \mathrm{kWhha}^{-1}$. Wheat was most energy efficient crop compared to rice and barley, whereas barley achieved the highest water productivity.

\subsection{Analysis of energy indices and balance energy indices in varieties rice production under traditional and semi-mechanized system condition}

The inputs used in varieties rice production under two farming system and their energy equivalents and output energy equivalent were illustrated in "Tables 3 and 4". About 848.7 $\mathrm{h}$ human labor, $37.2 \mathrm{~h}$ machinery power, $1000 \mathrm{~m} 3$ water, $5 \mathrm{~L}$ chemical poison and $127.2 \mathrm{~L}$ diesel fuel for total operations were used in varieties rice production under traditional on a hectare basis; Also $106.85 \mathrm{~L}$ depreciation power in this system was used. The highest use of nitrogen fertilizer $(105.8 \mathrm{~kg} / \mathrm{ha})$, phosphorus $(21 \mathrm{~kg} / \mathrm{ha})$ and potassium $(82 \mathrm{~kg} / \mathrm{ha})$ were observed in Gohar rice. The lowest use seed in varieties rice production under traditional was observed in Gohar rice ( $30 \mathrm{~kg} / \mathrm{ha}$ ). About $663.3 \mathrm{~h}$ human labor, $47.3 \mathrm{~h}$ machinery power, $1000 \mathrm{~m} 3$ water, $5 \mathrm{~L}$ chemical poison and $142.1 \mathrm{~L}$ diesel fuel for total operations were used in varieties rice production under traditional on a hectare basis; Also 119.36 L depreciation power in this system was used. The highest use of nitrogen fertilizer (105.8 kg/ha), phosphorus (21 kg/ha) and potassium (82 kg/ha) were observed in Gohar rice. The lowest use seed in varieties rice production under traditional was observed in Gohar rice (20 $\mathrm{kg} / \mathrm{ha})$.

In "Figure 6" (traditional system) and "Figure 7" (semi-mechanized system), eight groups of reserves of production of studied figures according to percentage of total energy of reserve were observed. Results showed that highest shares of this amount were reported for machinery, water, diesel fuel, chemical fertilizer and depreciation for per diesel fuel in all varieties rice production respectively. The energy inputs of seed, human labor and chemical poison were found to be quite low compared to the other inputs used in all varieties rice production respectively. 
The highest percent of compositions, amounts, production energy, and production energy to consumption energy ratio in rice paddy were obtained from starch as compared with protein and fat; the lowest consumption energy to production energy ratio in rice paddy was obtained from starch as compared with protein and fat "Table 8". Results of "Table 8" showed that breed varieties (Khazar, Hybrid and Gohar) because of suitable genetic specifications have higher operation in compared with local varieties (Hashemi and Alikazemi); the highest amounts (protein: 551.76, fat: 183.92 and starch: 6688), production energy (protein: $2207040 \mathrm{~kg} / \mathrm{ha}$, fat: $1655280 \mathrm{~kg} / \mathrm{ha}$ and starch: $26752000 \mathrm{~kg} / \mathrm{ha}$ ), and production energy to consumption energy ratio (protein: 0.20 , fat: 0.15 and starch: 2.41 ) in rice paddy of traditional system and highest amounts (protein: 627, fat: 209 and starch: 7600), production energy (protein: $2508000 \mathrm{~kg} / \mathrm{ha}$, fat: $1881000 \mathrm{~kg} / \mathrm{ha}$ and starch: 30400000 $\mathrm{kg} / \mathrm{ha}$ ), and production energy to consumption energy ratio (protein: 0.21 , fat: 0.16 and starch: 2.51) in rice paddy of semi-mechanized observed in Gohar rice.

The highest percent of compositions, amounts, production energy, and production energy to consumption energy ratio in rice husk were obtained from starch as compared with fat and protein; the lowest consumption energy to production energy ratio in rice husk was obtained from starch as compared with fat and protein "Table 9". Results of "Table 9" showed that breed varieties (Khazar, Hybrid and Gohar) because of suitable genetic specifications have higher operation in compared with local varieties (Hashemi and Alikazemi); the highest amounts (protein: 107.22, fat: 107.64 and starch:1045), production energy (protein: $428868 \mathrm{~kg} / \mathrm{ha}$, fat: $968715 \mathrm{~kg} / \mathrm{ha}$ and starch: $4180000 \mathrm{~kg} / \mathrm{ha}$ ), and production energy to consumption energy ratio (protein: 0.04 , fat: 0.09 and starch: 0.38 ) in rice husk of traditional system and highest amounts (protein: 121.84, fat: 122.31 and starch: 1187.50), production energy (protein: $487350 \mathrm{~kg} / \mathrm{ha}$, fat: $1100813 \mathrm{~kg} / \mathrm{ha}$ and starch: $4750000 \mathrm{~kg} / \mathrm{ha}$ ), and production energy to consumption energy ratio (protein: 0.04 , fat: 0.09 and starch: 0.39 ) in rice husk of semi-mechanized observed in Gohar rice.

The highest percent of compositions, amounts, production energy, and production energy to consumption energy ratio in rice straw were obtained from starch as compared with protein and fat; the lowest consumption energy to production energy ratio in rice straw was obtained from starch as compared with protein and fat "Table 10". Results of "Table 10" showed that breed varieties (Khazar, Hybrid and Gohar) because of suitable genetic specifications have higher operation in compared with local varieties (Hashemi and Alikazemi); the highest amounts (protein: 490.76, fat: 148.37 and starch:4941.83), production energy (protein: $1963036 \mathrm{~kg} / \mathrm{ha}$, fat: $1335321 \mathrm{~kg} / \mathrm{ha}$ and starch: 19767316 $\mathrm{kg} / \mathrm{ha}$ ), and production energy to consumption energy ratio (protein: 0.18 , fat: 0.12 and starch: 1.87) in rice straw of traditional system and highest amounts (protein:557.67, fat: 168.60 and starch: 6515.68), production energy (protein: $2230668 \mathrm{~kg} / \mathrm{ha}$, fat: $1517373 \mathrm{~kg} / \mathrm{ha}$ and starch: $22462308 \mathrm{~kg} / \mathrm{ha}$ ), and production energy to consumption energy ratio (protein: 0.18 , fat: 0.13 and starch: 1.86) in rice straw of semi-mechanized observed in Gohar rice. 

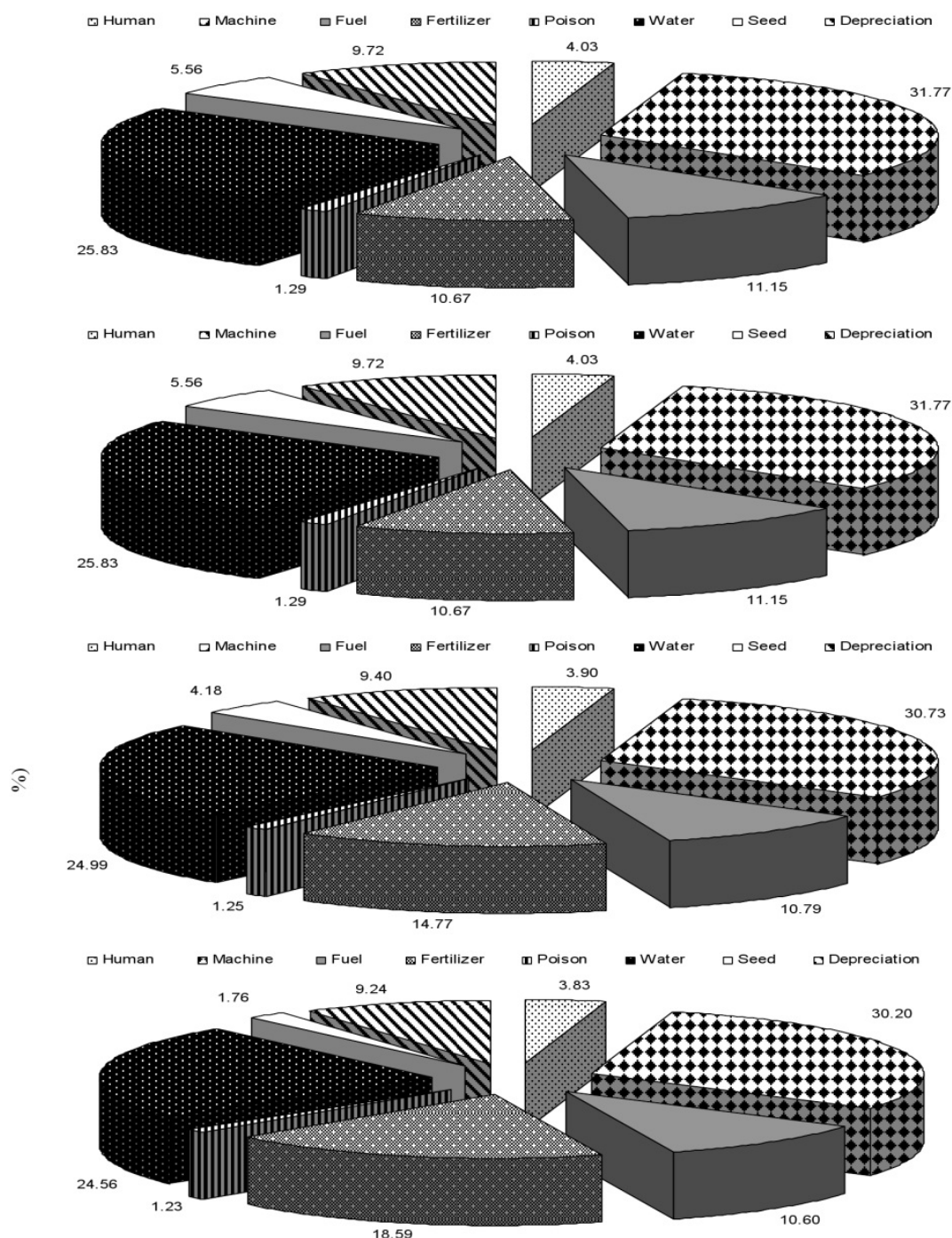

20
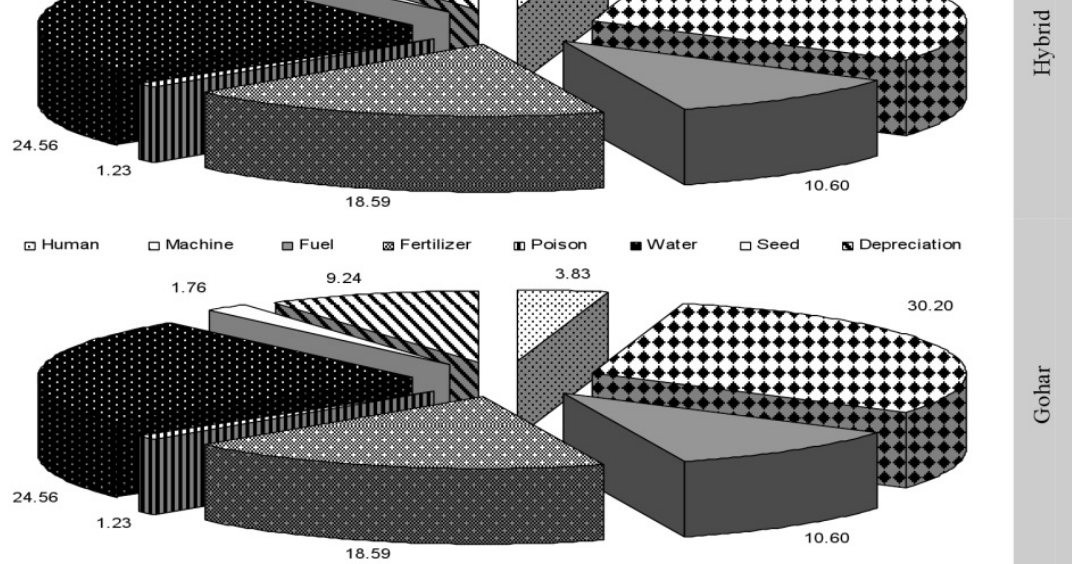

Figure 6. The share (\%) production inputs for varieties rice under traditional system condition 

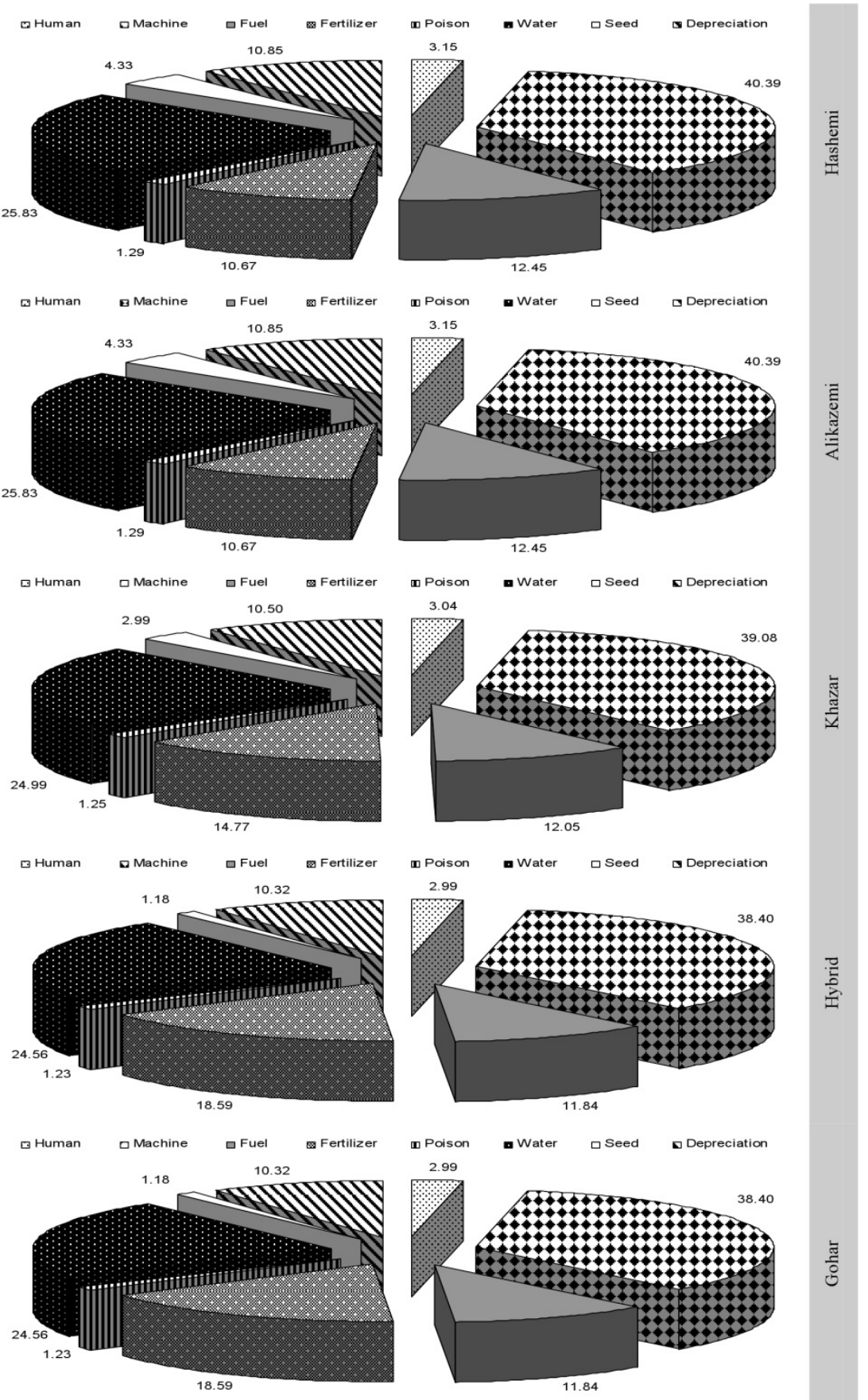

Figure 7. The share $(\%)$ production inputs for varieties rice under semi-mechanized system condition 


\begin{tabular}{|c|c|c|c|c|c|c|c|}
\hline $\begin{array}{c}\text { Varieties } \\
\text { rice }\end{array}$ & Item & $\begin{array}{c}\text { Percent of } \\
\text { compositions }\end{array}$ & $\begin{array}{c}\text { Energy } \\
\text { per gram } \\
(\mathrm{kcal})\end{array}$ & $\begin{array}{c}\text { Amounts } \\
(\mathrm{kg} / \mathrm{ha})\end{array}$ & $\begin{array}{c}\text { Production } \\
\text { energy } \\
(\mathrm{kcal} / \mathrm{ha})\end{array}$ & $\frac{\text { Production energy }}{\text { Consumption energy }}$ & $\frac{\text { Consumption energy }}{\text { Production energy }}$ \\
\hline \multicolumn{8}{|c|}{ Traditional system } \\
\hline \multirow{3}{*}{ Hashemi } & Protein & 6.6 & 4 & 232.32 & 929280 & 0.09 & 11.34 \\
\hline & Fat & 2.2 & 9 & 77.44 & 696960 & 0.07 & 15.12 \\
\hline & Starch & 80 & 4 & 2816 & 11264000 & 1.07 & 0.94 \\
\hline \multirow{3}{*}{$\begin{array}{l}\text { Alikaze } \\
\mathrm{mi}\end{array}$} & Protein & 6.6 & 4 & 275.88 & 1103520 & 0.10 & 9.55 \\
\hline & Fat & 2.2 & 9 & 91.96 & 827640 & 0.08 & 12.73 \\
\hline & Starch & 80 & 4 & 3344 & 13376000 & 1.27 & 0.79 \\
\hline \multirow{4}{*}{ Khazar } & Protein & 6.6 & 4 & 319.44 & 1277760 & 0.12 & 8.53 \\
\hline & Fat & 2.2 & 9 & 106.48 & 958320 & 0.09 & 11.37 \\
\hline & Starch & 80 & 4 & 3872 & 15488000 & 1.42 & 0.70 \\
\hline & Protein & 6.6 & 4 & 435.6 & 1742400 & 0.16 & 6.36 \\
\hline \multirow[t]{2}{*}{ Hybrid } & Fat & 2.2 & 9 & 145.2 & 1306800 & 0.12 & 8.48 \\
\hline & Starch & 80 & 4 & 5280 & 21120000 & 1.91 & 0.52 \\
\hline \multirow{3}{*}{ Gohar } & Protein & 6.6 & 4 & 551.76 & 2207040 & 0.20 & 5.02 \\
\hline & Fat & 2.2 & 9 & 183.92 & 1655280 & 0.15 & 6.70 \\
\hline & Starch & 80 & 4 & 6688 & 26752000 & 2.41 & 0.41 \\
\hline \multicolumn{8}{|c|}{ Semi-mechanized system } \\
\hline \multirow{3}{*}{ Hashemi } & Protein & 6.6 & 4 & 264 & 1056000 & 0.09 & 10.87 \\
\hline & Fat & 2.2 & 9 & 88 & 792000 & 0.07 & 14.50 \\
\hline & Starch & 80 & 4 & 3200 & 12800000 & 1.11 & 0.90 \\
\hline \multirow{3}{*}{$\begin{array}{c}\text { Alikaze } \\
\mathrm{mi}\end{array}$} & Protein & 6.6 & 4 & 313.5 & 1254000 & 0.11 & 9.16 \\
\hline & Fat & 2.2 & 9 & 104.5 & 940500 & 0.08 & 12.21 \\
\hline & Starch & 80 & 4 & 3800 & 15200000 & 1.32 & 0.76 \\
\hline \multirow{3}{*}{ Khazar } & Protein & 6.6 & 4 & 363 & 1452000 & 0.12 & 8.15 \\
\hline & Fat & 2.2 & 9 & 121 & 1089000 & 0.09 & 10.87 \\
\hline & Starch & 80 & 4 & 4400 & 17600000 & 1.49 & 0.67 \\
\hline \multirow{3}{*}{ Hybrid } & Protein & 6.6 & 4 & 495 & 1980000 & 0.16 & 6.11 \\
\hline & Fat & 2.2 & 9 & 165 & 1485000 & 0.12 & 8.14 \\
\hline & Starch & 80 & 4 & 6000 & 24000000 & 1.98 & 0.50 \\
\hline \multirow{3}{*}{ Gohar } & Protein & 6.6 & 4 & 627 & 2508000 & 0.21 & 4.82 \\
\hline & Fat & 2.2 & 9 & 209 & 1881000 & 0.16 & 6.43 \\
\hline & Starch & 80 & 4 & 7600 & 30400000 & 2.51 & 0.40 \\
\hline
\end{tabular}

Table 8. Items of energy balance indices in rice paddy production under traditional and semimechanized system condition

The highest percent of compositions, amounts, production energy, and production energy to consumption energy ratio in rice biomass were obtained from starch as compared with protein and fat; the lowest consumption energy to production energy ratio in rice biomass was obtained from starch as compared with protein and fat "Table 11". Results of "Table 11" showed that breed varieties (Khazar, Hybrid and Gohar) because of suitable genetic specifications have higher operation in compared with local varieties (Hashemi and Alikazemi); the highest amounts (protein: 1087.52, fat: 355.91 and starch:12259.26), 
production energy (protein: $4350060 \mathrm{~kg} / \mathrm{ha}$, fat: $32032260 \mathrm{~kg} / \mathrm{ha}$ and starch: $49037040 \mathrm{~kg} / \mathrm{ha}$ ), and production energy to consumption energy ratio (protein: 0.41 , fat: 0.30 and starch: 4.65 ) in rice biomass of traditional system and highest amounts (protein:1235.80, fat: 404.44 and starch: 13930.87), production energy (protein: $4943180 \mathrm{~kg} / \mathrm{ha}$, fat: $3639978 \mathrm{~kg} / \mathrm{ha}$ and starch: $55723120 \mathrm{~kg} / \mathrm{ha}$ ), and production energy to consumption energy ratio (protein: 0.47 , fat: 0.35 and starch: 5.29) in rice biomass of semi-mechanized observed in Gohar rice.

\begin{tabular}{|c|c|c|c|c|c|c|c|}
\hline \multirow{3}{*}{$\begin{array}{l}\text { Varieties } \\
\text { rice }\end{array}$} & \multirow{3}{*}{ Item } & \multirow{3}{*}{$\begin{array}{c}\text { Percent of } \\
\text { compositions }\end{array}$} & \multirow{3}{*}{$\begin{array}{c}\text { Energy } \\
\text { per } \\
\text { gram } \\
(\mathrm{kcal}) \\
\end{array}$} & \multirow{3}{*}{$\begin{array}{l}\text { Amounts } \\
(\mathrm{kg} / \mathrm{ha})\end{array}$} & \multirow{3}{*}{$\begin{array}{c}\text { Productio } \\
\text { n } \\
\text { energy } \\
\text { (kcal/ha) }\end{array}$} & \multirow{3}{*}{$\frac{\text { Production energy }}{\text { Consumption energy }}$} & \multirow{3}{*}{$\frac{\text { Consumption energy }}{\text { Production energy }}$} \\
\hline & & & & & & & \\
\hline & & & & & & & \\
\hline \multicolumn{8}{|c|}{ Traditional system } \\
\hline \multirow{3}{*}{ Hashemi } & Protein & 5.13 & 4 & 41.71 & 166828 & 0.02 & 63.18 \\
\hline & Fat & 5.15 & 9 & 41.87 & 376826 & 0.04 & 27.97 \\
\hline & Starch & 50 & 4 & 406.50 & 1626000 & 0.15 & 6.48 \\
\hline \multirow{3}{*}{ Alikazemi } & Protein & 5.13 & 4 & 53.61 & 214434 & 0.02 & 49.15 \\
\hline & Fat & 5.15 & 9 & 53.82 & 484358 & 0.05 & 21.76 \\
\hline & Starch & 50 & 4 & 522.50 & 2090000 & 0.20 & 5.04 \\
\hline \multirow{3}{*}{ Khazar } & Protein & 5.13 & 4 & 62.07 & 248292 & 0.02 & 43.88 \\
\hline & Fat & 5.15 & 9 & 62.32 & 560835 & 0.05 & 19.43 \\
\hline & Starch & 50 & 4 & 605.00 & 2420000 & 0.22 & 4.50 \\
\hline \multirow{3}{*}{ Hybrid } & Protein & 5.13 & 4 & 84.65 & 338580 & 0.03 & 32.74 \\
\hline & Fat & 5.15 & 9 & 84.98 & 764775 & 0.07 & 14.49 \\
\hline & Starch & 50 & 4 & 825.00 & 3300000 & 0.30 & 3.36 \\
\hline \multirow{3}{*}{ Gohar } & Protein & 5.13 & 4 & 107.22 & 428868 & 0.04 & 25.85 \\
\hline & Fat & 5.15 & 9 & 107.64 & 968715 & 0.09 & 11.44 \\
\hline & Starch & 50 & 4 & 1045.00 & 4180000 & 0.38 & 2.65 \\
\hline \multicolumn{8}{|c|}{ Semi-mechanized system } \\
\hline \multirow{4}{*}{ Hashemi } & Protein & 5.13 & 4 & 51.30 & 205200 & 0.02 & 55.96 \\
\hline & Fat & 5.15 & 9 & 51.50 & 463500 & 0.04 & 24.77 \\
\hline & Starch & 50 & 4 & 500.00 & 2000000 & 0.17 & 5.74 \\
\hline & Protein & 5.13 & 4 & 60.94 & 243778 & 0.02 & 47.11 \\
\hline \multirow[t]{2}{*}{ Alikazemi } & Fat & 5.15 & 9 & 61.18 & 550638 & 0.05 & 20.85 \\
\hline & Starch & 50 & 4 & 594.00 & 2376000 & 0.21 & 4.83 \\
\hline \multirow{3}{*}{ Khazar } & Protein & 5.13 & 4 & 70.54 & 282150 & 0.02 & 41.96 \\
\hline & Fat & 5.15 & 9 & 70.81 & 637313 & 0.05 & 18.57 \\
\hline & Starch & 50 & 4 & 687.50 & 2750000 & 0.23 & 4.30 \\
\hline \multirow{3}{*}{ Hybrid } & Protein & 5.13 & 4 & 96.19 & 384750 & 0.03 & 31.43 \\
\hline & Fat & 5.15 & 9 & 96.56 & 869063 & 0.07 & 13.92 \\
\hline & Starch & 50 & 4 & 937.50 & 3750000 & 0.31 & 3.22 \\
\hline \multirow{3}{*}{ Gohar } & Protein & 5.13 & 4 & 121.84 & 487350 & 0.04 & 24.81 \\
\hline & Fat & 5.15 & 9 & 122.31 & 1100813 & 0.09 & 10.99 \\
\hline & Starch & 50 & 4 & 1187.50 & 4750000 & 0.39 & 2.55 \\
\hline
\end{tabular}

Table 9. Items of energy balance indices in rice husk production under traditional and semimechanized system condition 


\begin{tabular}{|c|c|c|c|c|c|c|c|}
\hline \multirow{2}{*}{$\begin{array}{l}\text { Varieties } \\
\text { rice }\end{array}$} & \multirow{2}{*}{ Item } & \multirow{2}{*}{$\begin{array}{c}\text { Percent of } \\
\text { compositions }\end{array}$} & \multirow{2}{*}{$\begin{array}{c}\text { Energy } \\
\text { per } \\
\text { gram } \\
\text { (kcal) }\end{array}$} & \multirow{2}{*}{$\begin{array}{l}\text { Amounts } \\
(\mathrm{kg} / \mathrm{ha})\end{array}$} & \multirow{2}{*}{$\begin{array}{c}\text { Production } \\
\text { energy } \\
\text { (kcal/ha) }\end{array}$} & \multirow{2}{*}{$\frac{\text { Production energy }}{\text { Consumption energy }}$} & \multirow{2}{*}{$\frac{\text { Consumption energy }}{\text { Production energy }}$} \\
\hline & & & & & & & \\
\hline \multicolumn{8}{|c|}{ Traditional system } \\
\hline \multirow{4}{*}{ Hashemi } & Protein & 4.3 & 4 & 190.79 & 763164 & 0.07 & 13.81 \\
\hline & Fat & 1.3 & 9 & 57.68 & 519129 & 0.05 & 20.30 \\
\hline & Starch & 43 & 4 & 1921.22 & 7684884 & 0.73 & 1.37 \\
\hline & Protein & 4.3 & 4 & 245.36 & 981432 & 0.09 & 10.74 \\
\hline \multirow[t]{3}{*}{ Alikazemi } & Fat & 1.3 & 9 & 74.18 & 667602 & 0.06 & 15.79 \\
\hline & Starch & 43 & 4 & 2470.70 & 9882792 & 0.94 & 1.07 \\
\hline & Protein & 4.3 & 4 & 284.10 & 1136404 & 0.10 & 9.59 \\
\hline \multirow[t]{3}{*}{ Khazar } & Fat & 1.3 & 9 & 85.89 & 773019 & 0.07 & 14.09 \\
\hline & Starch & 43 & 4 & 2860.83 & 11443324 & 1.05 & 0.95 \\
\hline & Protein & 4.3 & 4 & 387.43 & 1549720 & 0.14 & 7.15 \\
\hline \multirow[t]{3}{*}{ Hybrid } & Fat & 1.3 & 9 & 117.13 & 1054170 & 0.10 & 10.52 \\
\hline & Starch & 43 & 4 & 3901.33 & 15605320 & 1.41 & 0.71 \\
\hline & Protein & 4.3 & 4 & 490.76 & 1963036 & 0.18 & 5.65 \\
\hline \multirow[t]{2}{*}{ Gohar } & Fat & 1.3 & 9 & 148.37 & 1335321 & 0.12 & 8.30 \\
\hline & Starch & 43 & 4 & 4941.83 & 19767316 & 1.78 & 0.56 \\
\hline \multicolumn{8}{|c|}{ Semi-mechanized system } \\
\hline \multirow{3}{*}{ Hashemi } & Protein & 4.3 & 4 & 234.82 & 939292 & 0.08 & 12.23 \\
\hline & Fat & 1.3 & 9 & 70.99 & 638937 & 0.06 & 17.97 \\
\hline & Starch & 43 & 4 & 2364.61 & 9458452 & 0.82 & 1.21 \\
\hline \multirow{3}{*}{ Alikazemi } & Protein & 4.3 & 4 & 278.86 & 1115420 & 0.10 & 10.29 \\
\hline & Fat & 1.3 & 9 & 84.31 & 758745 & 0.07 & 15.13 \\
\hline & Starch & 43 & 4 & 2808.01 & 11232020 & 0.98 & 1.02 \\
\hline \multirow{3}{*}{ Khazar } & Protein & 4.3 & 4 & 322.84 & 1291376 & 0.11 & 9.17 \\
\hline & Fat & 1.3 & 9 & 97.60 & 878436 & 0.07 & 13.48 \\
\hline & Starch & 43 & 4 & 3250.96 & 13003856 & 1.10 & 0.91 \\
\hline \multirow{3}{*}{ Hybrid } & Protein & 4.3 & 4 & 440.28 & 1761108 & 0.15 & 6.87 \\
\hline & Fat & 1.3 & 9 & 133.11 & 1197963 & 0.10 & 10.10 \\
\hline & Starch & 43 & 4 & 4433.49 & 17733948 & 1.47 & 0.68 \\
\hline \multirow{3}{*}{ Gohar } & Protein & 4.3 & 4 & 557.67 & 2230668 & 0.18 & 5.42 \\
\hline & Fat & 1.3 & 9 & 168.60 & 1517373 & 0.13 & 7.97 \\
\hline & Starch & 43 & 4 & 5615.58 & 22462308 & 1.86 & 0.54 \\
\hline
\end{tabular}

Table 10. Items of energy balance indices in rice straw production under traditional and semimechanized system condition

Results of "Table 12" showed that breed varieties (Khazar, Hybrid and Gohar) because of suitable genetic specifications have higher operation in compared with local varieties (Hashemi and Alikazemi); the highest paddy yield $(8360 \mathrm{~kg} / \mathrm{ha})$, consumption energy (11084731 kcal/ha), production energy (30614320 kcal/ha) and production energy to consumption energy ratio (2.76) in rice paddy of traditional system and highest paddy yield (9500 kg/ha), consumption energy (12093473 kcal/ha), production energy (34789000 kcal/ha) 
and production energy to consumption energy ratio (2.88) in rice paddy of semi-mechanized observed in Gohar rice. Energy per unit for rice varieties under to farming system was equaled. Highest Consumption energy to production energy ratio for rice varieties under to farming system was observed in Hashemi rice. Energy balance efficiency (production energy to consumption energy ratio) in this study was calculated 2.76 and 2.88; showing the affective use of energy in the agro ecosystems rice paddy production.

\begin{tabular}{|c|c|c|c|c|c|c|c|}
\hline $\begin{array}{l}\text { Varieties } \\
\text { rice }\end{array}$ & Item & $\begin{array}{c}\text { Percent of } \\
\text { compositions }\end{array}$ & $\begin{array}{c}\text { Energy } \\
\text { per } \\
\text { gram } \\
(\mathrm{kcal}) \\
\end{array}$ & $\begin{array}{c}\text { Amounts } \\
\text { (kg/ha) }\end{array}$ & $\begin{array}{c}\text { Production } \\
\text { energy } \\
\text { (kcal/ha) }\end{array}$ & $\frac{\text { Production energy }}{\text { Consumption energy }}$ & $\frac{\text { Consumption energy }}{\text { Production energy }}$ \\
\hline \multicolumn{8}{|c|}{ Traditional system } \\
\hline \multirow{4}{*}{ Hashemi } & Protein & 5.5 & 4 & 437.64 & 1750540 & 0.17 & 6.02 \\
\hline & Fat & 1.8 & 9 & 143.23 & 1289034 & 0.12 & 8.18 \\
\hline & Starch & 62 & 4 & 4933.34 & 19733360 & 1.87 & 0.53 \\
\hline & Protein & 5.5 & 4 & 543.73 & 2174920 & 0.21 & 4.85 \\
\hline \multirow[t]{2}{*}{ Alikazemi } & Fat & 1.8 & 9 & 177.95 & 1601532 & 0.15 & 6.58 \\
\hline & Starch & 62 & 4 & 6129.32 & 24517280 & 2.33 & 0.43 \\
\hline \multirow{4}{*}{ Khazar } & Protein & 5.5 & 4 & 629.59 & 2518340 & 0.24 & 4.33 \\
\hline & Fat & 1.8 & 9 & 206.05 & 1854414 & 0.18 & 5.87 \\
\hline & Starch & 62 & 4 & 7097.14 & 28388560 & 2.69 & 0.38 \\
\hline & Protein & 5.5 & 4 & 858.55 & 3434200 & 0.33 & 3.23 \\
\hline \multirow[t]{2}{*}{ Hybrid } & Fat & 1.8 & 9 & 280.98 & 2528820 & 0.24 & 4.38 \\
\hline & Starch & 62 & 4 & 9678.20 & 38712800 & 3.67 & 0.29 \\
\hline \multirow{3}{*}{ Gohar } & Protein & 5.5 & 4 & 1087.52 & 4350060 & 0.41 & 2.55 \\
\hline & Fat & 1.8 & 9 & 355.91 & 3203226 & 0.30 & 3.46 \\
\hline & Starch & 62 & 4 & 12259.26 & 49037040 & 4.65 & 0.23 \\
\hline \multicolumn{8}{|c|}{ Semi-mechanized system } \\
\hline \multirow{4}{*}{ Hashemi } & Protein & 5.5 & 4 & 520.36 & 2081420 & 0.20 & 5.52 \\
\hline & Fat & 1.8 & 9 & 170.30 & 1532682 & 0.15 & 7.49 \\
\hline & Starch & 62 & 4 & 5865.82 & 23463280 & 2.23 & 0.49 \\
\hline & Protein & 5.5 & 4 & 617.93 & 2471700 & 0.23 & 4.65 \\
\hline \multirow[t]{2}{*}{ Alikazemi } & Fat & 1.8 & 9 & 202.23 & 1820070 & 0.17 & 6.31 \\
\hline & Starch & 62 & 4 & 6965.70 & 27862800 & 2.64 & 0.41 \\
\hline \multirow{3}{*}{ Khazar } & Protein & 5.5 & 4 & 715.44 & 2861760 & 0.27 & 4.14 \\
\hline & Fat & 1.8 & 9 & 234.14 & 2107296 & 0.20 & 5.62 \\
\hline & Starch & 62 & 4 & 8064.96 & 32259840 & 3.06 & 0.37 \\
\hline \multirow{3}{*}{ Hybrid } & Protein & 5.5 & 4 & 975.65 & 3902580 & 0.37 & 3.10 \\
\hline & Fat & 1.8 & 9 & 319.30 & 2873718 & 0.27 & 4.21 \\
\hline & Starch & 62 & 4 & 10998.18 & 43992720 & 4.17 & 0.27 \\
\hline \multirow{3}{*}{ Gohar } & Protein & 5.5 & 4 & 1235.80 & 4943180 & 0.47 & 2.45 \\
\hline & Fat & 1.8 & 9 & 404.44 & 3639978 & 0.35 & 3.32 \\
\hline & Starch & 62 & 4 & 13930.78 & 55723120 & 5.29 & 0.22 \\
\hline
\end{tabular}

Table 11. Items of energy balance indices in rice biomass production under traditional and semimechanized system condition 


\begin{tabular}{|c|c|c|c|c|c|}
\hline Energy balance indices & Hashemi & Alikazemi & Khazar & Hybrid & Gohar \\
\hline \multicolumn{6}{|c|}{ Traditional system } \\
\hline Grain yield (kg/ha) & 3520 & 4180 & 4840 & 6600 & 8360 \\
\hline Consumption energy ( $\mathrm{kcal} / \mathrm{ha})$ & 10539595 & 10539595 & 10894253 & 11084731 & 11084731 \\
\hline Production energy (kcal/ha) & 12890240 & 15307160 & 17724080 & 24169200 & 30614320 \\
\hline Energy per unit (kcal) & 3662 & 3662 & 3662 & 3662 & 3662 \\
\hline $\begin{array}{l}\text { Production energy/ } \\
\text { Consumption energy }\end{array}$ & 1.22 & 1.45 & 1.63 & 2.18 & 2.76 \\
\hline $\begin{array}{l}\text { Consumption energy/ } \\
\text { Production energy }\end{array}$ & 27.40 & 23.07 & 20.60 & 15.37 & 12.13 \\
\hline \multicolumn{6}{|c|}{ Semi-mechanized system } \\
\hline Grain yield (kg/ha) & 4000 & 4750 & 5500 & 7500 & 9500 \\
\hline Consumption energy ( $\mathrm{kcal} / \mathrm{ha})$ & 11483207 & 11483207 & 11837865 & 12093473 & 12093473 \\
\hline Production energy (kcal/ha) & 14648000 & 17394500 & 20141000 & 27465000 & 34789000 \\
\hline Energy per unit (kcal) & 3662 & 3662 & 3662 & 3662 & 3662 \\
\hline $\begin{array}{l}\text { Production energy/ } \\
\text { Consumption energy }\end{array}$ & 1.28 & 1.51 & 1.70 & 2.27 & 2.88 \\
\hline $\begin{array}{l}\text { Consumption energy/ } \\
\text { Production energy }\end{array}$ & 26.27 & 22.12 & 19.70 & 14.76 & 11.65 \\
\hline
\end{tabular}

Table 12. Analysis of energy balance indices in rice paddy production under traditional and semimechanized system condition

Results of "Table 13" showed that breed varieties (Khazar, Hybrid and Gohar) because of suitable genetic specifications have higher operation in compared with local varieties (Hashemi and Alikazemi); the highest husk yield (2090 kg/ha), consumption energy $(11084731 \mathrm{kcal} / \mathrm{ha})$, production energy $(5577583 \mathrm{kcal} / \mathrm{ha})$ and production energy to consumption energy ratio (0.50) in rice husk of traditional system and highest husk yield (2357 kg/ha), consumption energy (12093473 kcal/ha), production energy (6338163 kcal/ha) and production energy to consumption energy ratio (0.52) in rice husk of semi-mechanized observed in Gohar rice. Energy per unit for rice varieties under to farming system was equaled. Highest Consumption energy to production energy ratio for rice varieties under to farming system was observed in Hashemi rice. Energy balance efficiency (production energy to consumption energy ratio) in this study was calculated 0.50 and 0.52 ; showing the affective use of energy in the agro ecosystems rice husk production.

Results of "Table 14" showed that breed varieties (Khazar, Hybrid and Gohar) because of suitable genetic specifications have higher operation in compared with local varieties (Hashemi and Alikazemi); the highest straw yield (11413 kg/ha), consumption energy (11084731 kcal/ha), production energy (23065673 kcal/ha) and production energy to consumption energy ratio (2.08) in rice husk of traditional system and highest paddy yield $(12969 \mathrm{~kg} / \mathrm{ha})$, consumption energy (12093473 kcal/ha), production energy (26210349 $\mathrm{kcal} / \mathrm{ha}$ ) and production energy to consumption energy ratio (2.17) in rice husk of semimechanized observed in Gohar rice. Energy per unit for rice varieties under to farming system was equaled. Highest Consumption energy to production energy ratio for rice varieties under to farming system was observed in Hashemi rice. Energy balance efficiency (production energy to consumption energy ratio) in this study was calculated 2.08 and 2.17; showing the affective use of energy in the agro ecosystems rice straw production. 


\begin{tabular}{|c|c|c|c|c|c|}
\hline Energy balance indices & Hashemi & Alikazemi & Khazar & Hybrid & Gohar \\
\hline \multicolumn{6}{|c|}{ Traditional system } \\
\hline Grain yield (kg/ha) & 813 & 1045 & 1210 & 1650 & 2090 \\
\hline Consumption energy ( $\mathrm{kcal} / \mathrm{ha})$ & 10539595 & 10539595 & 10894253 & 11084731 & 11084731 \\
\hline Production energy (kcal/ha) & 2169653.1 & 2788792 & 3229127 & 4403355 & 5577583 \\
\hline Energy per unit (kcal) & 2669 & 2669 & 2669 & 2669 & 2669 \\
\hline $\begin{array}{l}\text { Production energy/ } \\
\text { Consumption energy }\end{array}$ & 0.21 & 0.26 & 0.30 & 0.40 & 0.50 \\
\hline $\begin{array}{l}\text { Consumption energy/ } \\
\text { Production energy }\end{array}$ & 97.63 & 75.95 & 67.80 & 50.59 & 39.94 \\
\hline \multicolumn{6}{|c|}{ Semi-mechanized system } \\
\hline Grain yield (kg/ha) & 1000 & 1188 & 1375 & 1875 & 2375 \\
\hline Consumption energy ( $\mathrm{kcal} / \mathrm{ha})$ & 11483207 & 11483207 & 11837865 & 12093473 & 12093473 \\
\hline Production energy (kcal/ha) & 2668700 & 3170416 & 3669463 & 5003813 & 6338163 \\
\hline Energy per unit (kcal) & 2669 & 2669 & 2669 & 2669 & 2669 \\
\hline $\begin{array}{l}\text { Production energy/ } \\
\text { Consumption energy }\end{array}$ & 0.23 & 0.28 & 0.31 & 0.41 & 0.52 \\
\hline $\begin{array}{l}\text { Consumption energy/ } \\
\text { Production energy }\end{array}$ & 86.48 & 72.79 & 64.84 & 48.57 & 38.35 \\
\hline
\end{tabular}

Table 13. Analysis of energy balance indices in rice husk production under traditional and semimechanized system condition

\begin{tabular}{|c|c|c|c|c|c|}
\hline Energy balance indices & Hashemi & Alikazemi & Khazar & Hybrid & Gohar \\
\hline \multicolumn{6}{|c|}{ Traditional system } \\
\hline Grain yield (kg/ha) & 4437 & 5706 & 6607 & 9010 & 11413 \\
\hline Consumption energy ( $\mathrm{kcal} / \mathrm{ha})$ & 10539595 & 10539595 & 10894253 & 11084731 & 11084731 \\
\hline Production energy (kcal/ha) & 8967177 & 11531826 & 13352747 & 18209210 & 23065673 \\
\hline Energy per unit (kcal) & 2021 & 2021 & 2021 & 2021 & 2021 \\
\hline $\begin{array}{l}\text { Production energy/ } \\
\text { Consumption energy }\end{array}$ & 0.85 & 1.09 & 1.23 & 1.64 & 2.08 \\
\hline $\begin{array}{l}\text { Consumption energy/ } \\
\text { Production energy }\end{array}$ & 35.48 & 27.59 & 24.63 & 18.38 & 14.51 \\
\hline \multicolumn{6}{|c|}{ Semi-mechanized system } \\
\hline Grain yield (kg/ha) & 5461 & 6485 & 7508 & 10239 & 12969 \\
\hline Consumption energy ( $\mathrm{kcal} / \mathrm{ha})$ & 11483207 & 11483207 & 11837865 & 12093473 & 12093473 \\
\hline Production energy (kcal/ha) & 11036681 & 13106185 & 15173668 & 20693019 & 26210349 \\
\hline Energy per unit (kcal) & 2021 & 2021 & 2021 & 2021 & 2021 \\
\hline $\begin{array}{l}\text { Production energy/ } \\
\text { Consumption energy }\end{array}$ & 0.96 & 1.14 & 1.28 & 1.71 & 2.17 \\
\hline $\begin{array}{l}\text { Consumption energy/ } \\
\text { Production energy }\end{array}$ & 31.41 & 26.45 & 23.55 & 17.64 & 13.93 \\
\hline
\end{tabular}

Table 14. Analysis of energy balance indices in rice straw production under traditional and semimechanized system condition 
Results of "Table 15" showed that breed varieties (Khazar, Hybrid and Gohar) because of suitable genetic specifications have higher operation in compared with local varieties (Hashemi and Alikazemi); the highest biomass yield (19773 kg/ha), consumption energy (11084731 kcal/ha), production energy (56590326 kcal/ha) and production energy to consumption energy ratio (5.37) in rice biomass of traditional system and highest biomass yield (22469 kg/ha), consumption energy (12093473 kcal/ha), production energy (6430278 $\mathrm{kcal} / \mathrm{ha}$ ) and production energy to consumption energy ratio (6.10) in rice biomass of semimechanized observed in Gohar rice. Energy per unit for rice varieties under to farming system was equaled. Highest consumption energy to production energy ratio for rice varieties under to farming system was observed in Hashemi rice. Energy balance efficiency (production energy to consumption energy ratio) in this study was calculated 5.37 and 6.10; showing the affective use of energy in the agro ecosystems rice biomass production.

\begin{tabular}{|c|c|c|c|c|c|}
\hline Energy balance indices & Hashemi & Alikazemi & Khazar & Hybrid & Gohar \\
\hline \multicolumn{6}{|c|}{ Traditional system } \\
\hline Grain yield (kg/ha) & 7957 & 9886 & 11447 & 15610 & 19773 \\
\hline Consumption energy (kcal/ha) & 10539595 & 10539595 & 10894253 & 11084731 & 11084731 \\
\hline Production energy (kcal/ha) & 22772934 & 28293732 & 32761314 & 44675820 & 56590326 \\
\hline Energy per unit (kcal) & 2862 & 2862 & 2862 & 2862 & 2862 \\
\hline $\begin{array}{l}\text { Production energy/ } \\
\text { Consumption energy }\end{array}$ & 2.16 & 2.68 & 3.11 & 4.24 & 5.37 \\
\hline $\begin{array}{l}\text { Consumption energy/ } \\
\text { Production energy }\end{array}$ & 14.73 & 11.86 & 10.58 & 7.90 & 6.23 \\
\hline \multicolumn{6}{|c|}{ Semi-mechanized system } \\
\hline Grain yield (kg/ha) & 9461 & 11235 & 13008 & 17739 & 22469 \\
\hline Consumption energy ( $\mathrm{kcal} / \mathrm{ha})$ & 11483207 & 11483207 & 11837865 & 12093473 & 12093473 \\
\hline Production energy (kcal/ha) & 27077382 & 32154570 & 37228896 & 50769018 & 64306278 \\
\hline Energy per unit (kcal) & 2862 & 2862 & 2862 & 2862 & 2862 \\
\hline $\begin{array}{l}\text { Production energy/ } \\
\text { Consumption energy }\end{array}$ & 2.57 & 3.05 & 3.53 & 4.82 & 6.10 \\
\hline $\begin{array}{l}\text { Consumption energy/ } \\
\text { Production energy }\end{array}$ & 13.50 & 11.37 & 10.12 & 7.58 & 5.99 \\
\hline
\end{tabular}

Table 15. Analysis of energy balance indices in rice biomass production under traditional and semimechanized system condition

\subsection{Correlation analysis of energy indices and balance energy indices for rice production}

Result of "Table 16" (balance energy indices) showed that between paddy yield, straw yield, husk yield and biomass yield with production energy and production energy to consumption energy ratio have a positive and very significant correlation, also between paddy yield, straw yield, husk yield and biomass yield with consumption energy to production energy ratio energy intensity a negative and significant correlation in probability level of $1 \%$ were recorded. 


\begin{tabular}{|c|c|c|c|c|c|}
\hline Item & Yield & $\begin{array}{l}\text { Consumption } \\
\text { Energy }\end{array}$ & $\begin{array}{c}\text { Production } \\
\text { energy }\end{array}$ & $\frac{\text { Production energy }}{\text { Consumption energy }}$ & $\frac{\text { Consumption energy }}{\text { Production energy }}$ \\
\hline Paddy yield & 1 & & & & \\
\hline Consumption energy & 0.58 & 1 & & & \\
\hline Production energy & $0.99^{* *}$ & 0.58 & 1 & & \\
\hline $\begin{array}{l}\text { Production energy/ } \\
\text { Consumption energy }\end{array}$ & $0.99^{* *}$ & 0.48 & $0.99^{* *}$ & 1 & \\
\hline $\begin{array}{l}\text { Consumption energy/ } \\
\text { Production energy }\end{array}$ & $-0.96^{* *}$ & $-0.50^{* *}$ & $-0.96^{* *}$ & $-0.97^{* *}$ & 1 \\
\hline Straw yield & 1 & & & & \\
\hline Consumption energy & 0.59 & 1 & & & \\
\hline Production energy & $0.99^{* *}$ & 0.59 & 1 & & \\
\hline $\begin{array}{l}\text { Production energy/ } \\
\text { Consumption energy }\end{array}$ & $0.99^{* *}$ & 0.49 & $0.99^{* *}$ & 1 & \\
\hline $\begin{array}{l}\text { Consumption energy/ } \\
\text { Production energy }\end{array}$ & $-0.96^{* *}$ & $-0.52^{* *}$ & $-0.96^{* *}$ & $-0.96^{* *}$ & 1 \\
\hline Husk yield & 1 & & & & \\
\hline Consumption energy & 0.59 & 1 & & & \\
\hline Production energy & $0.99^{* *}$ & 0.59 & 1 & & \\
\hline $\begin{array}{l}\text { Production energy/ } \\
\text { Consumption energy }\end{array}$ & $0.99^{* *}$ & 0.48 & $0.99^{* *}$ & 1 & \\
\hline $\begin{array}{l}\text { Consumption energy/ } \\
\text { Production energy }\end{array}$ & $-0.96^{* *}$ & $-0.52^{* *}$ & $-0.96^{* *}$ & $-0.96^{* *}$ & 1 \\
\hline Biomass yield & 1 & & & & \\
\hline Consumption energy & 0.59 & 1 & & & \\
\hline Production energy & $0.99^{* *}$ & 0.59 & 1 & & \\
\hline $\begin{array}{l}\text { Production energy/ } \\
\text { Consumption energy }\end{array}$ & $0.99^{* *}$ & 0.59 & $0.99^{* *}$ & 1 & \\
\hline $\begin{array}{l}\text { Consumption energy/ } \\
\text { Production energy }\end{array}$ & $-0.96^{* *}$ & $-0.51^{* *}$ & $-0.96^{* *}$ & $-0.96^{* *}$ & 1 \\
\hline
\end{tabular}

**and*respectively significant in $1 \%$ and $5 \%$ area

Table 16. Correlation of energy balance indices for rice production

Result of "Table 17" (energy indices) showed that between paddy yield, straw yield, husk yield and biomass yield with input energy, output energy, energy ratio, energy productivity, net energy gain and water and energy productivity have a positive and very significant correlation, also between paddy yield, straw yield, husk yield and biomass yield with energy intensity a negative and significant correlation in probability level of $1 \%$ were recorded.

\subsection{Growth analysis of rice varieties}

Most climate change studies benefit from crop models. Crop simulation models could provide an alternative, less time-consuming and inexpensive means of determining the optimum crop $\mathrm{N}$ requirements under management nitrogen conditions. The model ORYZA2000, which simulates the growth and development of rice under conditions of potential production, water and nitrogen limitations, Results of growth indices analysis of rice varieties "Figure 8" showed 
that breed varieties (Khazar, Hybrid and Gohar) higher growth indices rather than Hashemi local varieties (Hashemi and Alikazemi). Azarpour et al. [3] with study Evaluation of the ORYZA2000 model of rice cultivars in Guilan climate condition showed that the model ORYZA2000 can satisfactorily in Simulates processes of growth and development and grain yield of rice cultivars under weather conditions of Guilan. Therefore validated ORYZA2000 model can apply to research purposes for rice cultivars under weather conditions of Guilan.

\begin{tabular}{|c|c|c|c|c|c|c|c|c|}
\hline Item & Yield & $\begin{array}{l}\text { Input } \\
\text { energy }\end{array}$ & $\begin{array}{l}\text { Output } \\
\text { energy }\end{array}$ & $\begin{array}{l}\text { Energy } \\
\text { Ratio }\end{array}$ & $\begin{array}{l}\text { Energy } \\
\text { intensity }\end{array}$ & $\begin{array}{c}\text { Energy } \\
\text { productivity }\end{array}$ & $\begin{array}{c}\text { Net } \\
\text { energy } \\
\text { gain }\end{array}$ & $\begin{array}{c}\begin{array}{c}\text { Water and } \\
\text { energy } \\
\text { productivity }\end{array} \\
\end{array}$ \\
\hline Paddy yield & 1 & & & & & & & \\
\hline Input energy & $0.91^{* *}$ & 1 & & & & & & \\
\hline Output energy & $0.99^{* *}$ & $0.91^{* *}$ & 1 & & & & & \\
\hline Energy ratio & $0.99^{* *}$ & $0.86^{* *}$ & $0.99^{* *}$ & 1 & & & & \\
\hline Energy intensity & $-0.97^{* *}$ & $-0.90^{* *}$ & $-0.97^{* *}$ & $-0.97^{* *}$ & 1 & & & \\
\hline Energy productivity & $0.98^{* *}$ & $0.84^{* *}$ & $0.98^{* *}$ & $0.99^{* *}$ & $-0.96^{* *}$ & 1 & & \\
\hline Net energy gain & $0.99^{* *}$ & $0.89^{* *}$ & $0.99^{* * *}$ & $0.99^{* *}$ & $-0.97^{* *}$ & $0.99^{* *}$ & 1 & \\
\hline $\begin{array}{c}\text { Water and energy } \\
\text { productivity }\end{array}$ & $0.99^{* *}$ & $0.87^{* *}$ & $0.99^{* * *}$ & $0.99^{* *}$ & $-0.97^{* *}$ & $0.99^{* *}$ & $0.99^{* *}$ & 1 \\
\hline Straw yield & 1 & & & & & & & \\
\hline Input energy & $0.92^{* *}$ & 1 & & & & & & \\
\hline Output energy & $0.99^{* *}$ & $0.92^{* *}$ & 1 & & & & & \\
\hline Energy ratio & $0.99^{* *}$ & $0.87^{* *}$ & $0.99^{* *}$ & 1 & & & & \\
\hline Energy intensity & $-0.96^{* *}$ & $-0.83^{* *}$ & $-0.96^{* *}$ & $-0.96^{* *}$ & 1 & & & \\
\hline Energy productivity & $0.99^{* *}$ & $0.88^{* *}$ & $0.99^{* *}$ & $0.99^{* *}$ & $-0.96^{* *}$ & 1 & & \\
\hline Net energy gain & $0.99^{* *}$ & $0.90^{* *}$ & $0.99^{* *}$ & $0.99^{* *}$ & $-0.96^{* *}$ & $0.99^{* *}$ & 1 & \\
\hline $\begin{array}{l}\text { Water and energy } \\
\text { productivity }\end{array}$ & $0.99^{* *}$ & $0.87^{* *}$ & $0.99^{* *}$ & $0.99^{* *}$ & $-0.97^{* *}$ & $0.99^{* *}$ & $0.99^{* *}$ & 1 \\
\hline Husk yield & 1 & & & & & & & \\
\hline Input energy & $0.92^{* *}$ & 1 & & & & & & \\
\hline Output energy & $0.99^{* *}$ & $0.92^{* *}$ & 1 & & & & & \\
\hline Energy ratio & $0.99^{* *}$ & $0.87^{* *}$ & $0.99^{* *}$ & 1 & & & & \\
\hline Energy intensity & $-0.96^{* *}$ & $-0.88^{* *}$ & $-0.96^{* *}$ & $-0.96^{* *}$ & 1 & & & \\
\hline Energy productivity & $0.92^{* *}$ & $0.77^{* *}$ & $0.92^{* *}$ & $0.95^{* *}$ & $-0.94^{* *}$ & 1 & & \\
\hline Net energy gain & $0.93^{* *}$ & $0.71^{* *}$ & $0.93^{* * *}$ & $0.96^{* *}$ & $-0.89^{* *}$ & $0.93^{* *}$ & 1 & \\
\hline $\begin{array}{c}\text { Water and energy } \\
\text { productivity }\end{array}$ & $0.95^{* *}$ & $0.84^{* *}$ & $0.95^{* *}$ & $0.96^{* * *}$ & $-0.93^{* *}$ & $0.96^{* *}$ & $0.92^{* *}$ & 1 \\
\hline Biomass yield & 1 & & & & & & & \\
\hline Input energy & $0.92^{* *}$ & 1 & & & & & & \\
\hline Output energy & $0.99^{* *}$ & $0.92^{* *}$ & 1 & & & & & \\
\hline Energy ratio & $0.99^{* *}$ & $0.87^{* *}$ & $0.99^{* *}$ & 1 & & & & \\
\hline Energy intensity & $-0.96^{* *}$ & $-0.89^{* *}$ & $-0.96^{* *}$ & $-0.97^{* *}$ & 1 & & & \\
\hline Energy productivity & $0.99^{* *}$ & $0.97^{* *}$ & $0.99^{* *}$ & $0.99^{* *}$ & $-0.97^{* *}$ & 1 & & \\
\hline Net energy gain & $0.99^{* *}$ & $0.91^{* *}$ & $0.99^{* *}$ & $0.99^{* *}$ & $-0.96^{* *}$ & $0.99^{* *}$ & 1 & \\
\hline $\begin{array}{c}\text { Water and energy } \\
\text { productivity }\end{array}$ & $0.99^{* *}$ & $0.87^{* *}$ & $0.99^{* *}$ & $0.99^{* *}$ & $-0.97^{* *}$ & $0.99^{* *}$ & $0.99^{* *}$ & 1 \\
\hline
\end{tabular}

**and ${ }^{*}$ respectively significant in $1 \%$ and $5 \%$ area

Table 17. Correlation of energy indices for rice production 


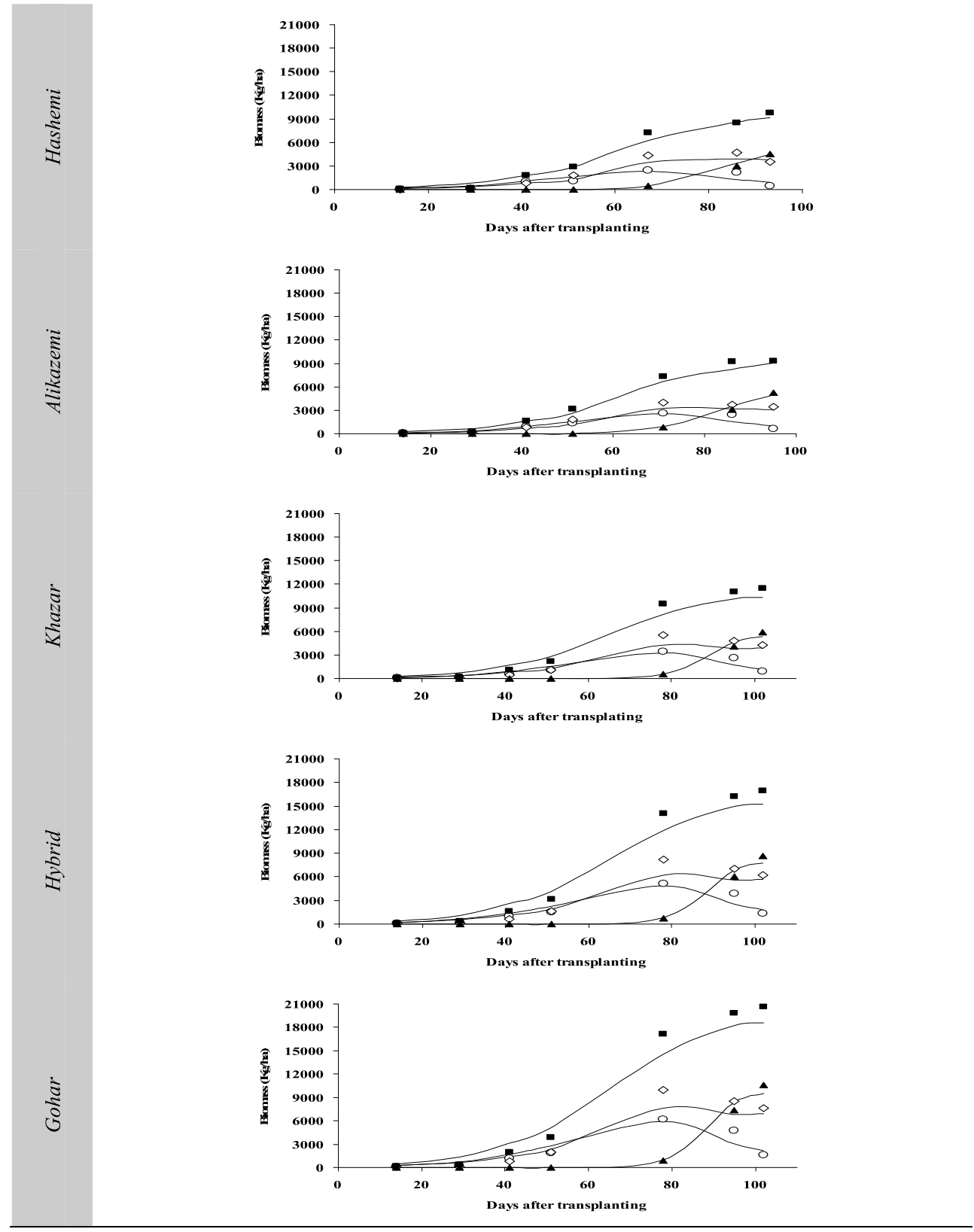

Figure 8. Simulation and measured of biomass of leaves $(0)$, stem $(\diamond)$, panicles $(\mathbf{\Lambda})$, and total aboveground biomass ( $\mathbf{-})$ 


\subsection{Cluster analysis of energy indices and balance energy indices for rice production}

In cluster analysis genotypes were classified into four groups based on Ward's method. Cluster analysis showed that Hybrid and Gohar varieties and Alikazemi, Khazar and Hashemi varieties in group similarities "Figure 9".

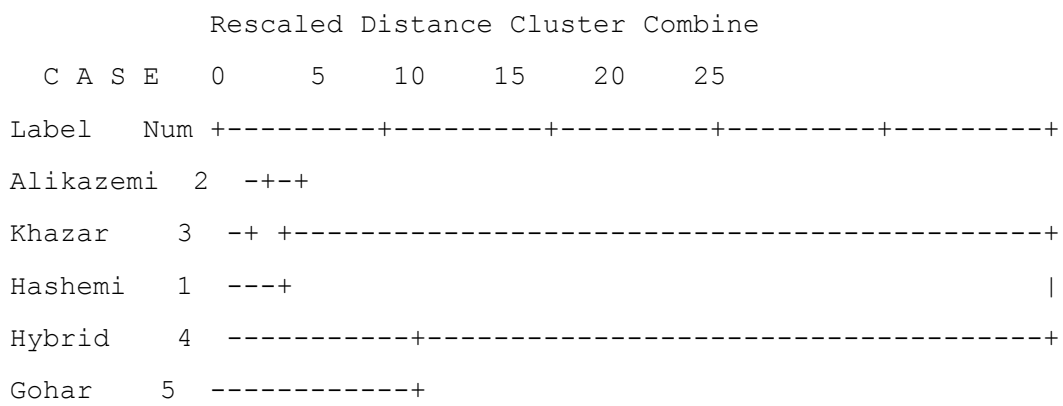

Figure 9. Dendrogram of rice genotypes based on different ward method

\subsection{Yield function}

Relation between amounts of energy efficiency (energy output to input energy ratio) and energy balance efficiency (production energy to consumption energy ratio) and their effect on paddy yield, straw yield, husk yield and biomass yield were showed in figure 10. Paddy yield, straw yield, husk yield and biomass yield were increased with of use energy efficiency and energy balance efficiency "Figure 10". Yield function of paddy yield, straw yield, husk yield and biomass yield obtained by following relationship "Figure 10".

\subsection{Economic analysis of varieties rice production under traditional and semi- mechanized system condition}

Crop profitability is the indicator for a farmer to decide what to grow and what and how much should be the energy inputs for growing that specific crop. Total cost of production in two farming systems and five varieties were showed that highest total cost of production in traditional system than semi-mechanized system and local varieties than breed varieties "Figure 11". The amount of higher consumption of human labor, chemical fertilizer, chemical poison and seed in traditional system lead to increasing total cost of production in this system in compared with semi-mechanized system. Also, because of suitable genetic specifications have higher operation in compared with local varieties. The suitable genetic specifications in breed varieties lead to reducing total cost of production in these varieties in compared with local varieties.

Gross value of production in two farming systems and five varieties were showed that highest gross value of production of semi-mechanized system than traditional system and 
breed varieties than local varieties "Figure 12". Highest gross value of production with average of 11717 \$/ha (semi-mechanized system) and 10311 \$/ha (traditional system) observed in Gohar rice.

Net return in two farming systems and five varieties were showed that highest net return of semi-mechanized system than traditional system and breed varieties than local varieties "Figure 13". Highest net return with average of 9391 \$/ha (semi-mechanized system) and 11239 \$/ha (traditional system) observed in Gohar rice.
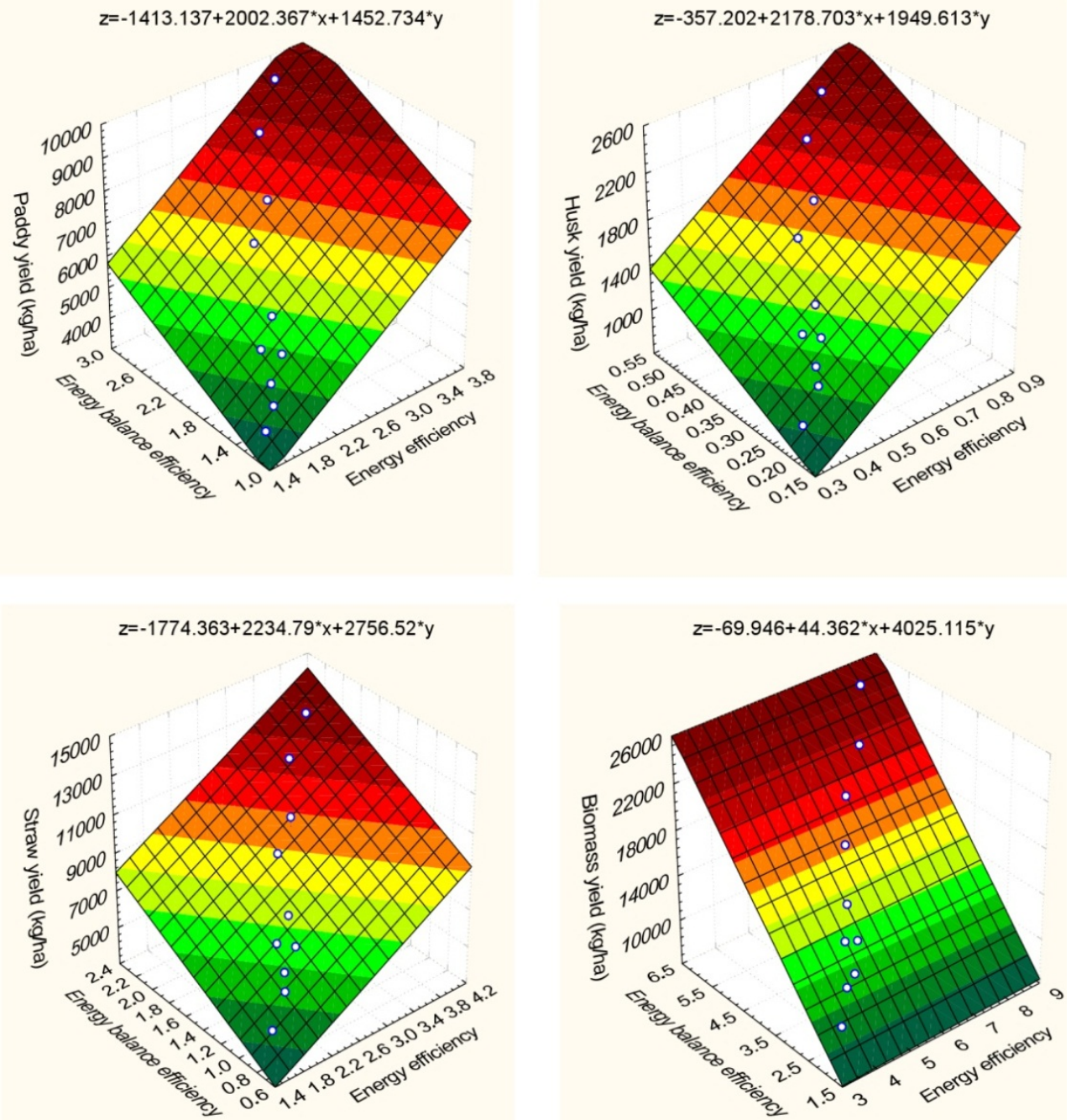

Figure 10. The effect of energy efficiency and energy balance on paddy yield, straw yield, husk yield and biomass yield 


\section{$\square$ non-mechanized system $\square$ mechanized system}

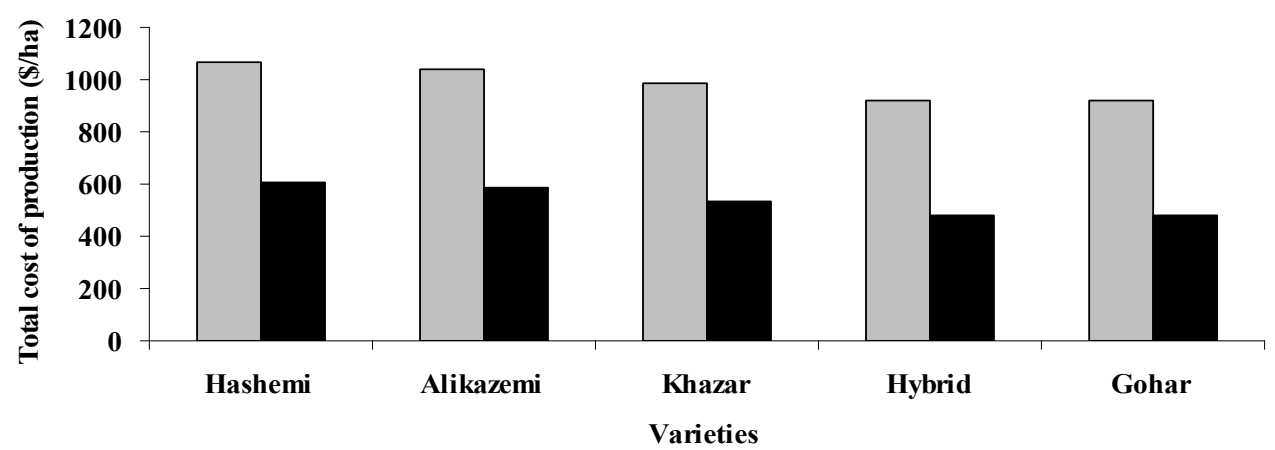

Figure 11. Total cost of production in varieties rice production under traditional and semi-mechanized system condition

$$
\square \text { non-mechanized system } \square \text { mechanized system }
$$

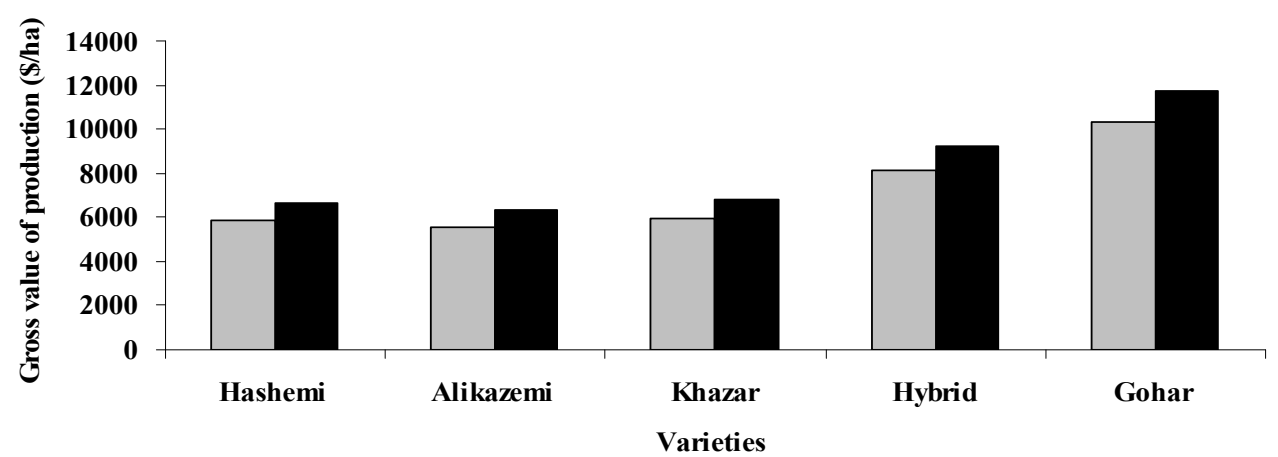

Figure 12. Gross value of production in varieties rice production under traditional and semimechanized system condition

Productivity in two farming systems and five varieties were showed that highest productivity of semi-mechanized system than traditional system and breed varieties than local varieties "Figure 14". Highest productivity with average of $19.87 \mathrm{~kg} / \$$ (semi-mechanized system) and $9.09 \mathrm{~kg} / \$$ (traditional system) observed in Gohar rice.

Benefit to cost ratio in two farming systems and five varieties were showed that highest benefit to cost ratio of semi-mechanized system than traditional system and breed varieties than local varieties "Figure 15". Highest benefit to cost ratio with average of 11.21 (semimechanized system) and 24.51 (traditional system) observed in Gohar rice. 
$\square$ non-mechanized system $\square$ mechanized system

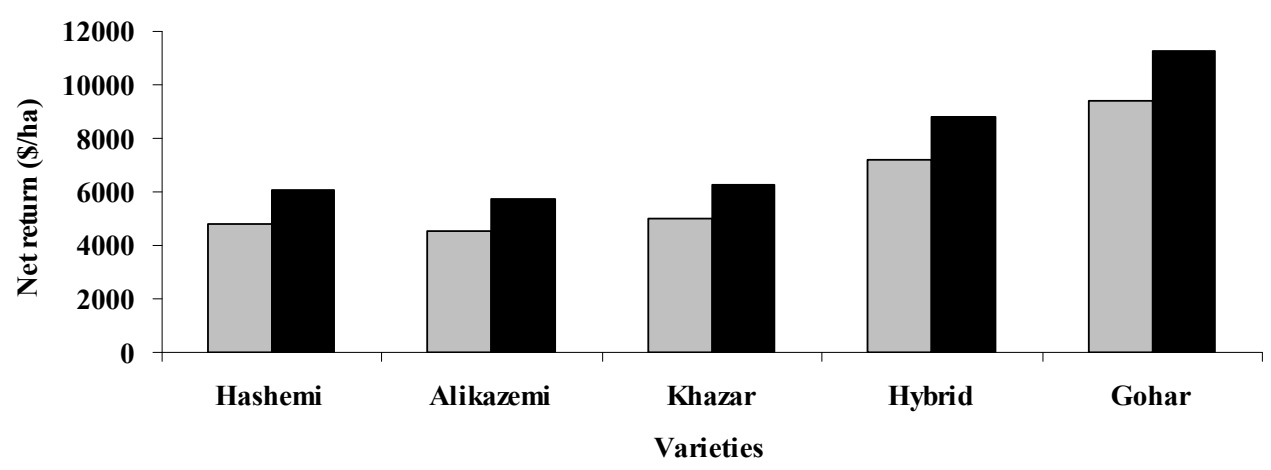

Figure 13. Net return in varieties rice production under traditional and semi-mechanized system condition

\section{$\square$ non-mechanized system $\square$ mechanized system}

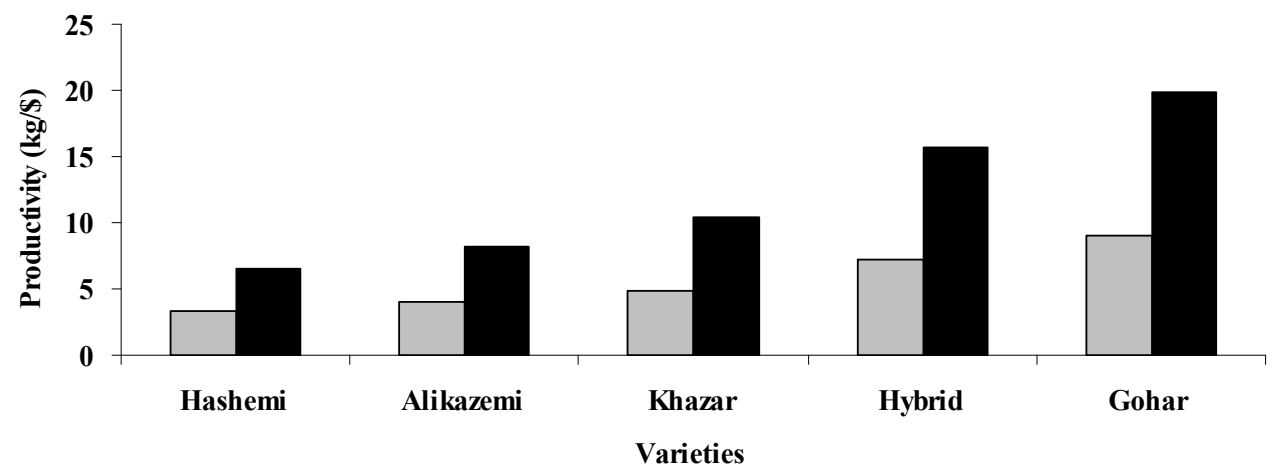

Figure 14. Productivity in varieties rice production under traditional and semi-mechanized system condition

Khan et al. [17] with study energy requirements and economic analysis of wheat, rice and barley production in Australia showed that Cost of production on wheat crop was 323, rice 896 and barley was A $\$ 246$ ha $^{-1}$. Rice grower obtained the highest return of $\mathrm{A} \$ 2088$, as compared to wheat and barley growers, who obtained A\$589 and 370 ha $^{-1}$. Therefore, the benefit-cost ratio was the highest on rice farms (3.33) as compared to wheat (2.82) and Barley (2.50). It was concluded that increase in energy consumption at farm level increased yield of rice, hence the farmers with higher cost of production could get better return of their crop [16]. 


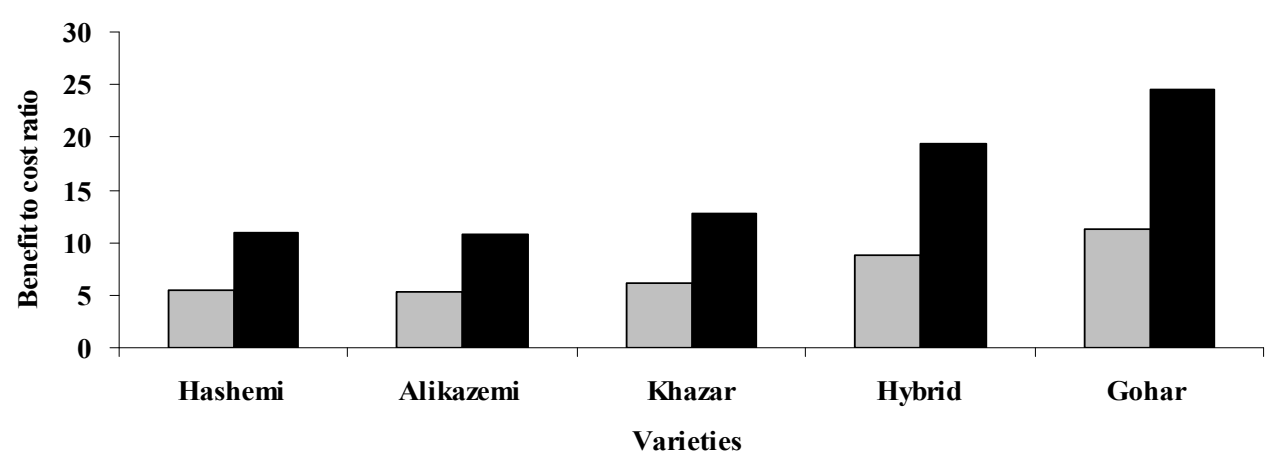

Figure 15. Benefit to cost ratio in varieties rice production under traditional and semi-mechanized system condition

\section{Conclusion}

Consider that breed varieties rice and semi-mechanized farming system are suitable case for increasing production of rice according to the limitation of rice fields of Guilan province (Iran). Identifying the way of developing and exploitation, energy indicators in agricultural section of Iran either in the light of having weak economical fundamentals or in the light of strict competition in global scene for obtaining better economical condition, helps that we lead our resources and facilities of our production in a direction that can obtain our suitable place in international occasions faster. According to the results of this research and studying the energy and economic analysis, we can say that the condition of the management of energy consumption in producing breed varieties (Khazar, Hybrid (GRH1) and Gohar (SA13)) are more suitable and according to the need of country about producing rice and limitation of energy sources which are mainly nonrenewable energy, producing breed varieties is a step towards sustainable agriculture.

\section{Author details}

Ebrahim Azarpour* and Maral Moraditochaee

Young Researchers and Elite Club, Lahijan Branch, Islamic Azad University, Lahijan, Iran

\section{References}

[1] Artacho P, Bonomelli C, Meza F (2009) Nitrogen Application in Irrigated Rice Grown in Mediterranean Conditions: Effects on Grain Yield, Dry Matter Production, Nitrogen Uptake, and Nitrogen Use Efficiency, Journal of Plant Nutrition. 32: 9, 1574-1593.

${ }^{*}$ Corresponding Author 
[2] Azarpour E (2012). Evaluation energy balance and energy indices of barley production under watered farming in north of Iran. ARPN Journal of Agricultural and Biological Science. 7 (3): 163-168.

[3] Azarpour E, Amiri E, Kashani A, Khodabandeh N, Moradi M (2012) Evaluation of the ORYZA2000 model of rice cultivars in Gilan climat condition. Agronomy and berrding Iran. Islamic Azad University, Lahijan, Iran. 8 (1). In press.

[4] Azarpour E, Moraditochaee M, Bozorgi HR (2012) Evaluation energy balance and energy indices of peanut production in north of Iran. African Journal of Agricultural Research. 7 (16): 2569-2574.

[5] Azarpour E, Moraditochaee M, Bozorgi HR (2012) Evaluation energy balance and energy indices of pumpkin production under dry land farming in north of Iran. Journal of Food, Agriculture \& Environment. In press.

[6] Azarpour E, Moraditochaee M, Bozorgi HR (2012) Evaluation energy balance and energy indices of wheat production under rain fed farming in north of Iran. African Journal of Agricultural Research. In press.

[7] Bouman BAM, Kropff MJ, Tuong TP, Wopereis MCS, Ten Berge HFM Van Laar HH (2001) ORYZA2000: Modeling lowland rice. Phillipines: International Rice Research Institute.

[8] Demirbas A (2003) Energy and environmental issues relating to greenhouse gas emissions in Turkey, Energy Conversion and Management. 44: 203-213.

[9] Dincer L (2001) Environmental issues: I-energy utilization. Energy Source. 23: 69-81.

[10] De Jonge AM (2004) Eco-efficiency improvement of a crop protection product: the perspective of the crop protection industry. Crop Protect. 23(12): 1177-1186.

[11] Eskandari Cherati F, Bahrami H, Asakereh A (2011). Energy survey of mechanized and traditional rice production system in Mazandaran Province of Iran. African Journal of Agricultural Research. 6 (11): 2565-2570.

[12] Fageria NK, Slaton NA, Baligar VC (2003) Nutrient management for improving lowland rice productivity and sustainability. Advances in Agronomy. 80: 63-152.

[13] Fageria NK (2007) Yield Physiology of Rice. Journal of Plant Nutrition. 30 (6): 843-879.

[14] Hatirli SA, Ozkan B, Fert K (2005) An econometric analysis of energy input output in Turkish agriculture. Renewable and sustainable energy reviews. 9: 608-623.

[15] Hulsbergen K, Feil J, Diepenbrock W (2002) Rates of nitrogen application required to achieve maximum energy efficiency for various crops: Result of a long- term experiment, Field Crops Research. 77: 113-135.

[16] Khan MA, Awan IU, Zafar J (2009). Energy requirement and economic analysis of rice production in western part of Pakistan. Soil \& Environ. 28(1): 60-67.

[17] Khan S, Khan MA, Latif N (2010) Energy requirements and economic analysis of wheat, rice and barley production in Australia. Soil \& Environ. 29(1): 61-68.

[18] Kizilaslan H (2009) Energy use and input-output energy analysis for apple production in Turkey. J. Food, Agric. Environ. 7(2): 419-423.

[19] Ma H, Oxley L, Gibson J, Kim B (2008) China's energy economy: Technical change, factor demand and interfactor/interfuel substitution. Energy Economics. 30: 2167-2183. 
[20] Mandel KG, Saha KP, Ghosh PK, Hati KM, Bandyopadhyay KK (2002) Bioenergy and economic analysis of soybean based crop production systems in central India. Biomass Bioenergy. 23: 337-345.

[21] Mohammadi A, Omid M (2010) Economical analysis and relation between energy inputs and yield of greenhouse cucumber production in Iran. Applied Energy. 87: 191196.

[22] Mohammadi A, Tabatabaeefar A, Shahin Sh, Rafiee Sh, Keyhani A (2008) Energy use and economical analysis of potato production in Iran a case study: Ardabil province. Energy Conversion and Management. 49: 3566-357

[23] Moradi, M, Azarpour E (2011) Study of energy indices for native and breed rice varieties production in Iran. World applied sciences journal. 13(1): 137-141.

[24] Ozkan B, Akcaoz H, Fert C (2004) Energy input output analysis in Turkish agriculture. Renewable Energy. 29: 39-51.

[25] Ozkan B, Akcaoz H, Karadcniz F (2003) Energy requirement and economic analysis of citrus production in Turkey. Energy Conversion and Management. 44: 46-56.

[26] Peykani GR, Kavoosi Kelashemi M, Sadat Barikani SH, Sasouli MR (2008) Comparison of Production Productivity of 3 Rice Varieties Including Long Grain Good Quality, Long Grain High Yielding and Hybrid Rice in Iran (Case Study: Gilan Province) American-Eurasian J. Agric. \& Environ. Sci. 4 (5): 625-632.

[27] Sartori L, Basso B, Bertocco M, Oliviero G (2005) Energy use and economic evaluation of a three year crop rotation for conservation and organic farming in NE Italy. Biosystems Engineering. 9(2): 245-250.

[28] Singh H, Mishra D, Nahar NM (2002). Energy use pattern in production agriculture of a typical village in Arid Zone India-Part. Energy Convers Manage. 43: 2275-2286.

[29] Streimikiene D, Klevas V, Bubeliene J (2007) Use of EU structural funds for sustainable energy development in new EU member states. Renew Sustain Energy Rev. 116: 116787.

[30] Taheri Garavand A, Asakereh A, Haghani K (2010) Investigation energy and economic analysis of Soya Bean production in North of Iran. American-Eurasian J. Agric. \& Environ. Sci. 7: 648-651.

[31] Yilrnaz L, Akcaoz H, Ozkan B (2005) An analysis of energy use and input costs for cotton production in Turkey, Renewable Energy. 30: 145-155. 